\title{
Raman Investigations to Identify Corallium rubrum in Iron Age Jewelry and Ornaments
}

\author{
Sebastian Fürst ${ }^{1,+}$, Katharina Müller ${ }^{2,+}$, Liliana Gianni ${ }^{2,+}$, Céline Paris ${ }^{3,+}$, \\ Ludovic Bellot-Gurlet $^{3,+}$, Christopher F.E. Pare ${ }^{1,+}$ and Ina Reiche ${ }^{2,4,+, *}$ \\ 1 Vor- und Frühgeschichtliche Archäologie, Institut für Altertumswissenschaften, Johannes \\ Gutenberg-Universität Mainz, Schillerstraße 11, Mainz 55116, Germany; fuerst@uni-mainz.de (S.F.); \\ pare@uni-mainz.de (C.F.E.P.) \\ 2 Sorbonne Universités, UPMC Université Paris 06, CNRS, UMR 8220, Laboratoire d'archéologie moléculaire \\ et structurale (LAMS), 4 Place Jussieu, 75005 Paris, France; katharina.muller@upmc.fr (K.M.); \\ lilianagianni@gmail.com (L.G.) \\ 3 Sorbonne Universités, UPMC Université Paris 06, CNRS, UMR 8233, De la molécule au nano-objets: \\ réactivité, interactions et spectroscopies (MONARIS), 4 Place Jussieu, 75005 Paris, France; \\ celine.paris@upmc.fr (C.P.); ludovic.bellot-gurlet@upmc.fr (L.B.-G.) \\ 4 Rathgen-Forschungslabor, Staatliche Museen zu Berlin-Preußischer Kulturbesitz, Schloßstraße 1 a, \\ Berlin 14059, Germany \\ * Correspondence: i.reiche@smb.spk-berlin.de or ina.reiche@upmc.fr; Tel.: +49-30-2664-27101 \\ + These authors contributed equally to this work.
}

Academic Editor: Steve Weiner

Received: 31 December 2015; Accepted: 1 June 2016; Published: 15 June 2016

\begin{abstract}
During the Central European Iron Age, more specifically between 600 and 100 BC, red precious corals (Corallium rubrum) became very popular in many regions, often associated with the so-called (early) Celts. Red corals are ideally suited to investigate several key questions of Iron Age research, like trade patterns or social and economic structures. While it is fairly easy to distinguish modern C. rubrum from bone, ivory or shells, archaeologists are confronted with ancient, hence altered, artifacts. Due to ageing processes, archaeological corals lose their intensive red color and shiny surface and can easily be confused with these other light colored materials. We propose a non-destructive multi-stage approach to identify archaeological corals amongst other biominerals used as ornament during the central European Iron Age with emphasis on optical examination and mobile Raman spectroscopy. Our investigations suggest that the noticeably high amount of misidentifications or at least uncertain material declarations existing in museums or even in the literature (around 15\%) could be overcome by the proposed approach. Furthermore, the range of different materials is higher than previously expected in archaeological research. This finding has implications for contemporary concepts of social structures and distribution networks during the Iron Age.
\end{abstract}

Keywords: corals; shells; Raman spectroscopy; biogenic carbonates; carotenoids; polyenes; color fading; material degradation; archaeology

\section{Introduction}

Since Neolithic [1-3] and maybe even in Paleolithic times, 30,000 years ago [4,5], the skeletons of red precious corals (Corallium rubrum (C. rubrum)) were used as jewelry and ornaments. Because of their shiny red color and their dense and hard structure, it is the most demanded coral species in the jewelry industry, which led to an intensive commercial harvesting during the 19th and early 20th century and, in the aftermath, to a decline of its stocks (e.g., [6,7]). 
Corallium rubrum is a species within the Corallium genus of the Corallidae family and belongs taxonomically to the Anthozoa class within the phylum Cnidaria (e.g., $[3,8,9])$. The Anthozoa class is divided into three subclasses (Octocorallia, Hexacorallia and Ceriantharia), with the first two as the most important, being determined according to their eight-fold radial symmetry, like C. rubrum, and the third subclass by hexaradial symmetry.

A living specimen of $C$. rubrum consists of three major components: the coral polyps are embedded in a living integument called the coenenchyme, sarcosome or coenosarc, which covers an axial skeleton [1,4,10-13]. In jewelry manufacturing, though, only the calcitic skeleton is of importance, which is why the $0.2-0.3 \mathrm{~mm}$-thin coenosarc is removed prior to processing $[1,3]$. Unpolished Corallium branches show very characteristic longitudinally-oriented grooves on their surface, as discussed in Section 3.1, deriving from large canals in the coenosarc, which connect the polyps with each other in order to transmit nutrition and information $[1,4,14]$.

The axial skeleton of C. rubrum consists of high-magnesium calcite (HMC) of $c a .88 \%$ Ca and compositionally $12 \% \mathrm{Mg}$ (in number of atoms) together with some minor and trace elements $[13,15,16]$. The organic matrix $(\mathrm{OM})$ of the axial skeleton of $C$. rubrum basically consists of acidic proteins and sugars [12]. Additionally, the OM contains small amounts of organic pigments. The biomineralization processes were investigated in several studies (e.g., [17-19]). Allemand and Bénazet-Tambutté [15] have shown that the skeletogenic epithelium in the coenosarc is responsible for the growth of the coral colony (from a few millimeters up to $1-2 \mathrm{~cm}$ per year $[1,11]$ ) by secretion of calcium carbonate, while the mechanical incorporation of sclerites produced by the scleroblasts only takes place in the apical part of the coral colony, i.e., the 1-cm terminal portion of the branches. However, new investigations of Perrin et al. have shown that the absence of sclerites from the annular part must be reconsidered, as well as the notion that there is no "cement" between the sclerites [17].

The organic pigment comprises various conjugated hydrocarbon chains, which are responsible for the intense red color of the coral. However, the exact structure of these organic compounds is still the subject of discussion. Several studies suggest a coloration due to carotenoids [8,9,11,20-22]. Other works propose unmethylated polyenes [23] and unsubstituted, all trans-polyacetylenic molecules [24], respectively. Several authors think that actually, there is a mixture of pigments each belonging to the same family [25,26]. Karampelas et al. [27] and Bergamonti et al. [28] showed that partially or completely demethylated polyenes with different conjugation lengths seem to be responsible for the colors of the species of the genus Corallium and most of the marine shells, whereas the red aragonitic hydroids of the species Stylaster roseus are colored by carotenoids, similar to those found in canthaxanthin.

Raman studies on mollusks and their pearls revealed at least four and up to nine pigments in the same pearl, even in homogeneously-pigmented zones [24,29]. Chain lengths ranging from 6-14 conjugated double bonds deriving from carotenoids with unmethylated polyacetylenic backbones of various conjugation lengths were reported to be responsible for the colors.

The identification of $C$. rubrum seems to be fairly easy for modern pieces, but can be difficult for those from archaeological records. Corallium rubrum loses its intense red color and shiny surface structure due to not yet fully understood degradation processes, which is why it can easily be mistaken for light colored materials, like bone, ivory, shells or even limestone, also used for jewelry in Central Europe during prehistoric times. Moreover, the corals and other biominerals were usually used as small polished studs or pearls (average diameter of only $0.5-1 \mathrm{~cm}$ ), which have only small, concealed surface characteristics. It is therefore not surprising that 80 years ago, many researchers did not know that white inlays could have been made from red coral. Today, however, there is a slight tendency to declare all light colored materials as C. rubrum.

Attempts have repeatedly been made to identify the raw material of the frequently-encountered and today whitish jewelry inlays using different analytical methods, as for instance $X$-ray fluorescence (XRF) [30-32], X-ray diffraction (XRD), isotope analysis, as well as electron microprobe (EMP) [32,33], micro-computed X-ray tomography $(\mu-\mathrm{CT})$ [34] and Raman spectroscopy [35]. These studies help toward better knowledge of the biominerals used for the manufacturing of precious objects. 
Schrickel et al. [35-38] recently used micro-X-ray tomography (micro-CT), digital microscopy, full-field micro-XRF using the X-ray-color camera, Raman spectroscopy and XRD to investigate mainly late Iron Age coral ornamented fibulae ("Mitteldeutsche Korallenfibeln") from Central Germany. Based on the $\mathrm{MgCO}_{3}$ contents and specific structural features, the authors conclude that most of the materials used to ornament the fibulae were nummulites or other Foraminifera, and not $C$. rubrum.

During the Central European Iron Age, more specifically between 600 and 100 BC, red precious corals (C. rubrum) became very popular in many regions, often associated with the so-called (early) Celts. Red corals are ideally suited to investigate several key questions of Iron Age research [39-44]. As a prestigious long-distance trade good, C. rubrum can change the social status of a grave or site and, yet, its whole interpretation. On a macro scale, the distribution of coral finds help to gain a better understanding of trade patterns, communication routes and Iron Age social structures. It is therefore very instructive to generate an approximation of the extent of the actual use of coral and to find out which other materials have been applied as jewelry ornaments at which time. A better identification of the raw material used for the manufacturing of ancient objects will also contribute to the reconstruction of the original appearance of the objects.

However, before these questions can be answered and interpreted, the first objective is to establish an investigation protocol for biominerals from archaeological sites to unambiguously identify C. rubrum on archaeological artifacts. Since most archaeological institutions do not have access to much scientific equipment and do not have the time for detailed investigations, this identification procedure must meet a few requirements. It has to be both efficient and reliable, and of course, the analyses must be non-invasive. This is why the proposed identification protocol focuses on visual and mesoscopic observations, as well as Raman spectroscopy. Since there are so many alleged coral objects (several thousand of individual pieces), the proposed approach must be flexible enough in order to study large collections with reasonable means. Studying the distribution of raw materials over large areas and time spans requires their reliable determination on representative collections. On basis of this methodology, a representative selection of archaeological artifacts was studied in order to test earlier attributions found in the literature or in museum inventories.

\section{Materials and Methods}

\subsection{Materials}

In order to establish a reliable catalogue of the structural features of archaeological corals, two successive steps are necessary. Ancient unprocessed corals and mollusks, which can be clearly determined as such, are the starting point. These are necessary to identify structural features caused by alterations, such as changes in color or surface texture. Secondly, a sufficiently large collection of recent corals and mollusks has been investigated as reference material (Table 1). It was considered important to use taxonomically-reliable specimens from the collections of natural history museums to avoid misinterpretation by using imitations of precious corals purchased on the free market $[3,11]$.

Attention was also paid to investigate as many different coral and mollusk species as possible, e.g., white coral, organ pipe coral (Tubipora musica) or Scleractinia. Furthermore, other species of the genus Corallium from the Indo-Pacific were examined [45]. Even fossil precious corals (6-7.2 million years old) and samples from the Atlantic Ocean were studied. Furthermore, care was taken to ensure that the coral samples of $C$. rubrum came from as many different Mediterranean regions as possible. Nowadays, C. rubrum mainly occurs between North Africa, Spain, France and Italy, but it can also be found in the adjacent Atlantic Ocean between the Algarve and Cape Verde [3,9,46,47]. Since both the archaeological coastal finds [48] and the written historical location information [49] match with the current regions of coral harvesting, there seems to have been hardly any shifts in terms of provenance since prehistoric times. 
Table 1. List of reference objects, which have been analyzed by Raman spectroscopy and/or by XRF. The number of obtained Raman spectra is significantly higher, because some objects showed several interesting and different-looking areas that were examined.

\begin{tabular}{|c|c|c|}
\hline Species* & Origin* & Analyzed Objects \\
\hline \multicolumn{3}{|c|}{ Corals (Anthozoa) } \\
\hline Corallium rubrum (red precious coral) & $\begin{array}{l}\text { French coast (Marseille), Greece, Italy (Sardinia, } \\
\text { Sicily, Tyrrhenian Sea), Malta, Spain (La Escala), } \\
\text { Portugal (Algarve) }\end{array}$ & 19 \\
\hline Corallium rubrum (Sciacca coral) & Italy (Sicily, Sciacca) & 1 \\
\hline Corallium sp., deep sea & Portugal (Azores, 1557 m depth) & 1 \\
\hline Corallium sp./konojoi(?) (white coral) & Japan & 1 \\
\hline Corallium sp. (white coral) & Unknown & 1 \\
\hline Corallium sp., Pleistocene & Italy (Sicily, Augusta) & 1 \\
\hline $\begin{array}{c}\text { Corallium sp., Miocene, Tortonian } \\
\text { 11.6-7.2 million years }\end{array}$ & Spain (Mazarrón) & 1 \\
\hline Corallium secundum (red Momo coral) & Taiwan & 1 \\
\hline Corallium elatius (porous Mushi coral) & Philippines, Nepal & 2 \\
\hline Tubipora musica (organ pipe coral) & Unknown, Red Sea or Indo-Pacific & 1 \\
\hline Scleractinia & Unknown & 2 \\
\hline \multicolumn{3}{|c|}{ Shells (Bivalvia) } \\
\hline Spondylus gaederopus (thorny/spiny oysters) & $\begin{array}{c}\text { Greece (Morea), Italy (Trieste, Sardinia); Egypt } \\
\text { (Red Sea, Hurghada) }{ }^{1}\end{array}$ & 5 \\
\hline Spondylus barbatus (thorny/spiny oysters) & Indo-Pacific & 1 \\
\hline Spondylus sp. (thorny/spiny oysters) & United Arab Emirates & 1 \\
\hline \multicolumn{3}{|c|}{ Sea Snails (Gastropoda) } \\
\hline $\begin{array}{l}\text { Cypraecassis testiculus } \\
\text { (reticulated cowrie helmet) }\end{array}$ & Dominican Republic, Cape Verde (Sao Vicente) ${ }^{1}$ & 2 \\
\hline Semicassis saburon (helmet/bonnet snail) & Italy (Naples) & 1 \\
\hline
\end{tabular}

It has to be noted that the number of potential raw materials, at least for the Iron Age period, is much smaller than today, since the archaeological record suggests that there has been no importation of corals or mollusks from farther away than the seas adjacent to Central Europe (Mediterranean Sea, Atlantic Ocean, North and Baltic Sea). As a consequence, all coral and mollusk species from the Indo-Pacific or the tropical areas of the Atlantic Ocean can be excluded when it comes to identification of Western European archaeological artifacts.

A total of 95 archaeological artifacts (see Table S1) and 41 recent corals and mollusks have been analyzed using Raman spectroscopy. Furthermore, 50 recent corals and mollusks and two coral inlays from the Iron Age gold helmet of Agris (département Charente, France) have been analyzed by XRF.

\subsection{Methods}

\subsubsection{Microscopy}

In order to investigate the characteristic structural features, the objects were examined using a digital Leica DVM 2000 microscope (Leica Microsystems GmbH, Wetzlar, Germany) with an optical zoom range from $50 \times-400 \times$ magnification and an analog Zeiss Microscope (Carl Zeiss AG, Oberkochen, Germany) with an attached digital camera and an optical zoom range from $16 \times-80 \times$ magnification. 


\subsubsection{Raman Spectroscopy}

Raman spectroscopy allows detecting both the mineral part and the organic pigments of red coral. Resonance or near-resonance Raman scattering is exceptionally sensitive to both pigment groups, the carotenoids and polyenes, even in very low concentrations [27]. Numerous studies on red corals or red colored marine shells were carried out using Raman spectroscopy $[8,11,18,20-28]$. Kupka et al. [26] state that a very small amount of organic matter is able to change the color of this coral from white to pink, leading to the conclusion that the Raman activity of such 'chromophores' is very high.

The Raman analyses were performed using various spectrometers (bench-top or portable) with various excitation wavelengths and under different experimental conditions to determine the most suitable settings (for a summary of the already used spectrometers and measurement conditions, see Table S2).

In Raman analyses of corals and mollusks, the choice of the best-suited laser wavelength depends on whether the colorants or the mineral phase are the focus of interest (see Figure 1). In general, the higher the wavelength, the better are the mineral phases detected, especially with $785 \mathrm{~nm}$, because of the fluorescence reduction with this wavelength and the out-of-resonance conditions for the pigment. The lower the wavelength, the better are the colorants detected, especially with 488 and $532 \mathrm{~nm}$, because for these organic molecules have a strong resonance effect, which enhances their Raman diffusion over the fluorescence emission and even mineral signature. The 632.8-nm wavelength turned out to be the best compromise to detect both features at the same time; however, not with the same intensity (sensitivity) as with the "ideal" wavelengths for each feature, respectively.

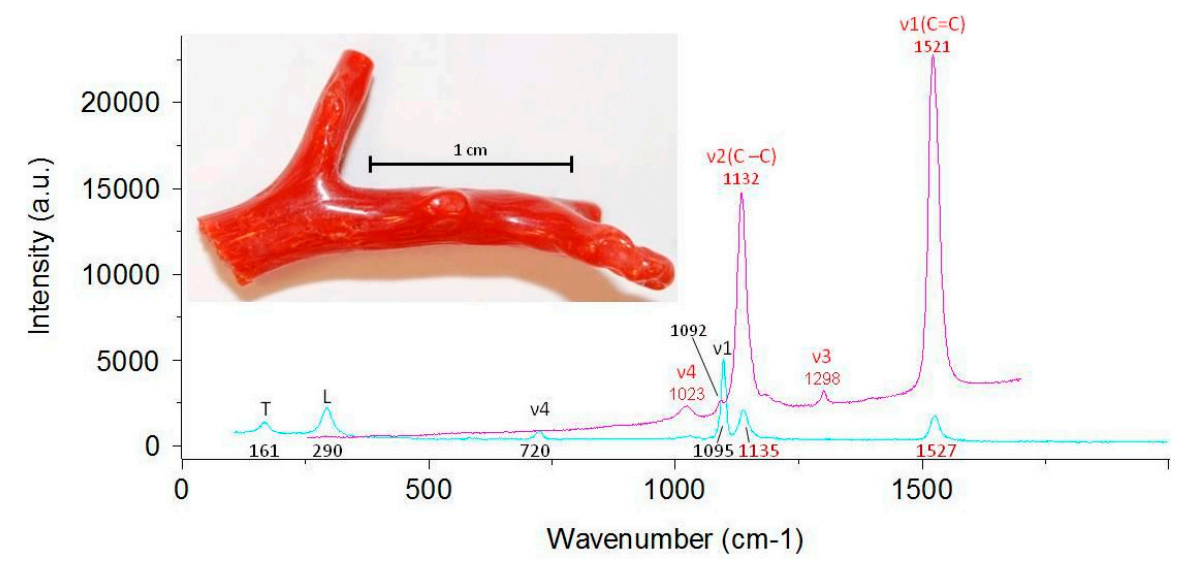

Figure 1. Raman spectrum of the same spot of a C. rubrum sample using $785 \mathrm{~nm}$ (blue) and $488 \mathrm{~nm}$ (red), indicating the visibility of different features of $C$. rubrum. Abbreviations: $\mathrm{T}=$ translation; $\mathrm{L}=$ libration; $v_{4}=$ in-plane bending; $v_{1}=$ symmetric stretching.

Figure 1 illustrates the different spectra obtained by a 785-nm and a 488-nm excitation under laboratory conditions. Among the features of the high magnesium calcite, the symmetric $\left(\mathrm{CO}_{3}\right)^{2-}$ stretching mode $\left(v_{1}\right)$ is the main band and occurs at around $1092 \mathrm{~cm}^{-1}$. Only two bands appear in the lattice vibration region of the high magnesium calcite spectrum: the libration at 290 and the translation at $161 \mathrm{~cm}^{-1}$. The $v_{4}$ in-plane bend is present at $720 \mathrm{~cm}^{-1}$. Several studies $[18,50,51]$ have shown that the peak positions of HMC shift towards higher wavenumber regions in the Raman spectrum. Thus, the peak positions of pure calcite are at around 156, 283, 713 and $1086 \mathrm{~cm}^{-1}$, respectively; $E_{\text {g,ext }}$ modes for the two first bands $(T, L)$ and $E_{g, \text { int }}\left(v_{4}\right)$ and $A_{1 g \text {,int }}\left(v_{1}\right)$ modes for the following. The aragonite spectrum of many mollusks differs from the calcite spectrum especially in the lattice vibration region with bands of medium intensity at 207 and $154 \mathrm{~cm}^{-1}$ plus other weak intensity bands, as well as a double band for the $v_{4}$ planar bending $\left(E_{g, \text { int }}\right)$ at 702 and $706 \mathrm{~cm}^{-1}$ (see discussion below).

Concerning the colorants, the two main bands with the highest intensity are the stretching modes of the $C=C$ double bonds $\left(v_{1}\right)$ at around $1520 \mathrm{~cm}^{-1}$ and the $C-C$ single bonds $\left(v_{2}\right)$ at around 
$1130 \pm 15 \mathrm{~cm}^{-1}$. Several studies have shown that Raman spectra of white areas on recent corals, mollusks or natural pearls do not show the characteristic bands of organic dye or only with very low intensities (as discussed below in Section 4.2) [11,18,26,29]. Observations have pointed out that the $v_{2}$ vibration enables a distinction between unsubstituted polyenes that can be found at about $1130 \pm 15 \mathrm{~cm}^{-1}$, while carotenoid bands appear at approximately $1155 \pm 15 \mathrm{~cm}^{-1}[24,25,52]$.

A part of the analyses was carried out "on-site" in the museums using portable equipment, which does not provide the same spectral resolution as laboratory spectrometers (see Table S2). In those cases, it is necessary to use a 785-nm excitation to determine the mineral phase and a 532-nm excitation for the colorant detection (which are the laser lines available for our portable instruments).

\section{Results}

\subsection{Optical Differences between the Surface Structures of Ancient and Recent Precious Corals}

From the end of the seventh until the middle of the fifth century BC, almost unprocessed C. rubrum was quite popular, especially worn as necklaces, pinheads or pendants. The natural state allows a comprehensive examination of the structural features. A representative selection of Iron Age artifacts, which are clearly identifiable as Corallium, is shown in Figure 2. Although these four examples look more or less faded, at least not as red as modern red precious corals, all of them still reveal small areas of red color, sometimes only visible by microscopical observations (see Figure 3c,f).

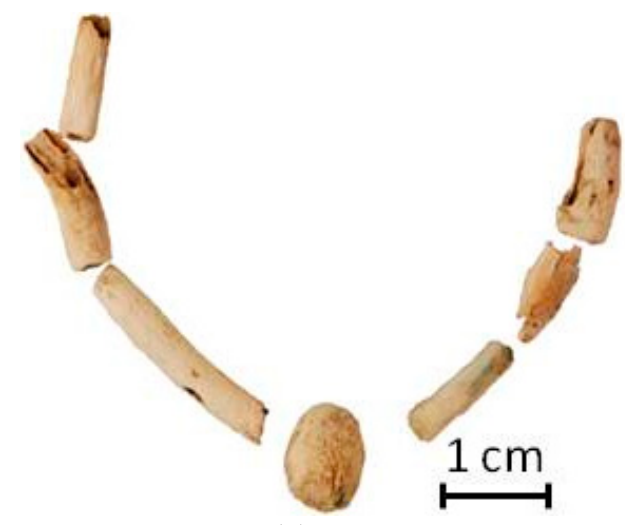

(a)

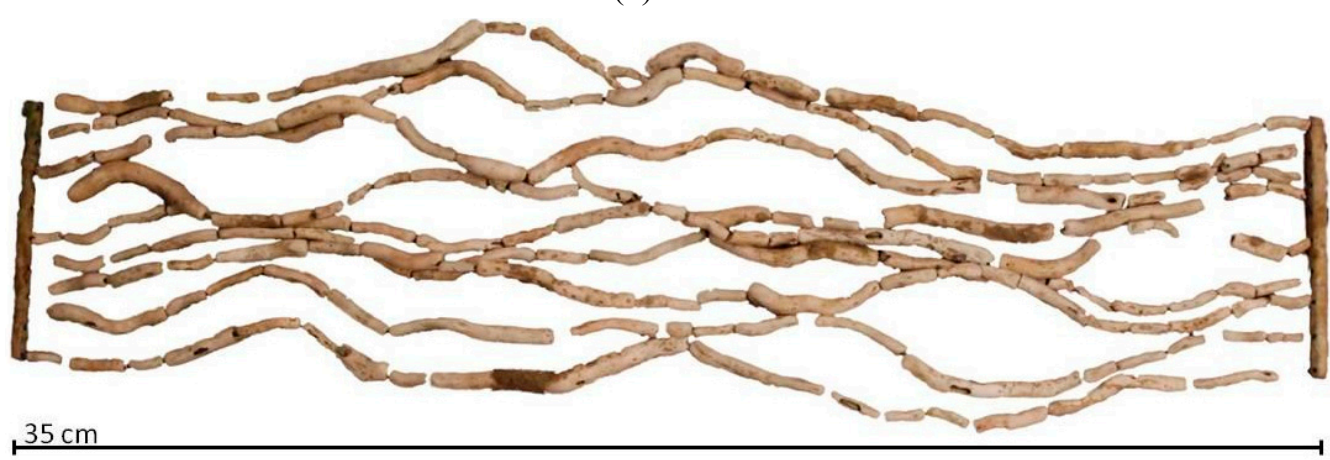

(b)

Figure 2. Cont. 


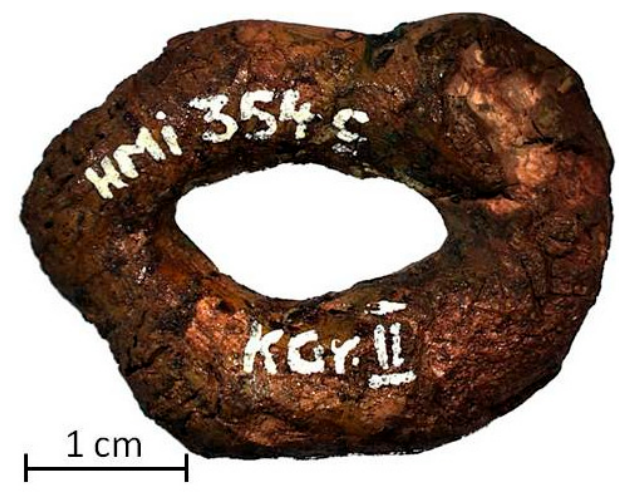

(c)

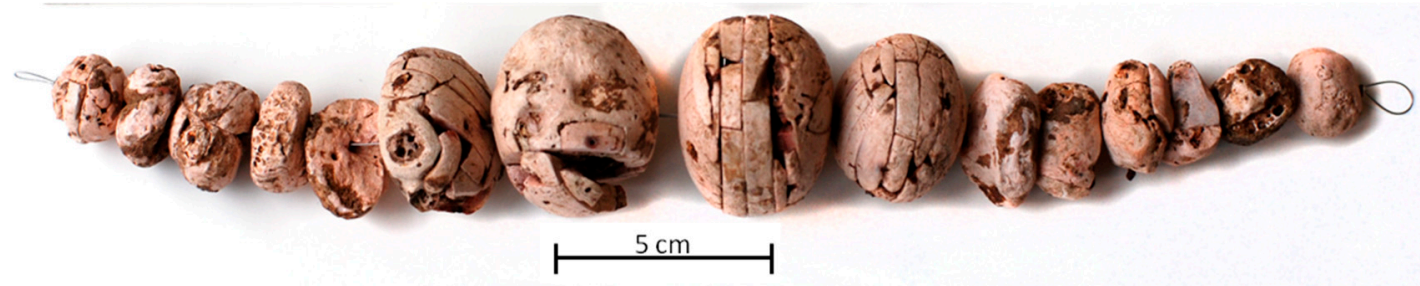

(d)

Figure 2. Examples of almost unprocessed corals from the Iron Age ( 620-450 BC) in southwestern Germany. (a) Necklace from Tomb 122 of the Magdalenenberg tumulus near Villingen-Schwenningen (Schwarzwald-Baar-Kreis). A detail is shown in Figure 3e. (b) Pectoral necklace from a tumulus near Allensbach-Kaltbrunn (Landkreis Konstanz). (c) Piece of oddly circular-shaped coral branch from Burial 6 of the Hohmichele tumulus near Altheim-Heiligkreuztal. (d) Necklace of single coral pieces and egg-sized bulbs, composed of several lamellae from the burial of a young woman at Esslingen-Sirnau.

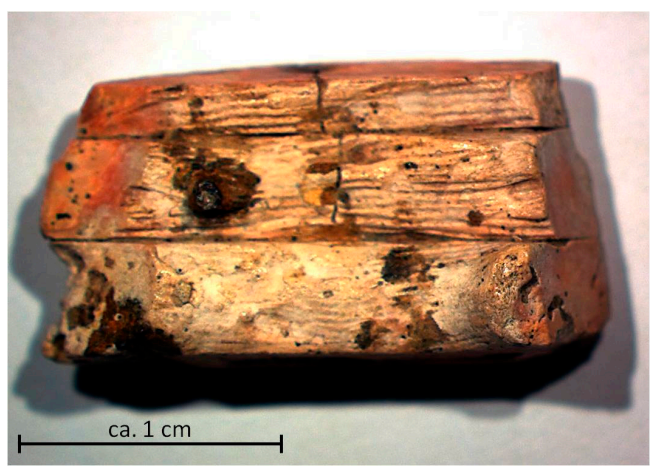

(a)

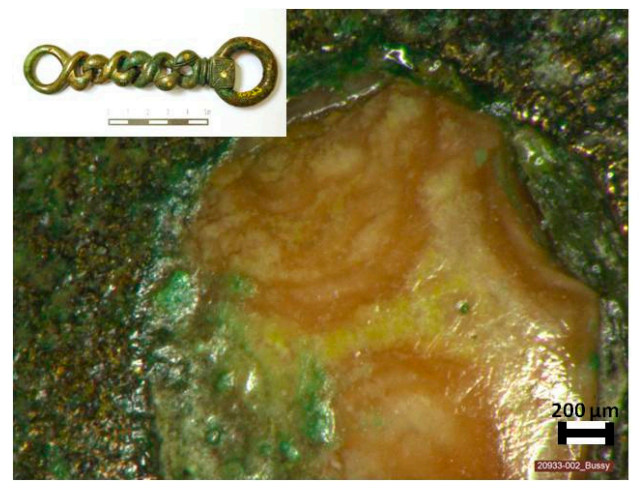

(c)

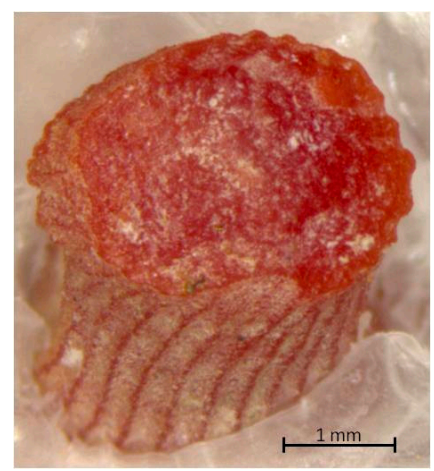

(b)

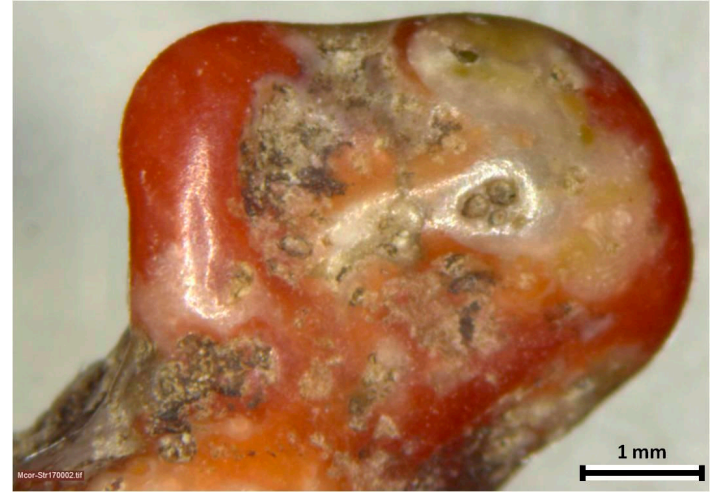

(d)

Figure 3. Cont. 


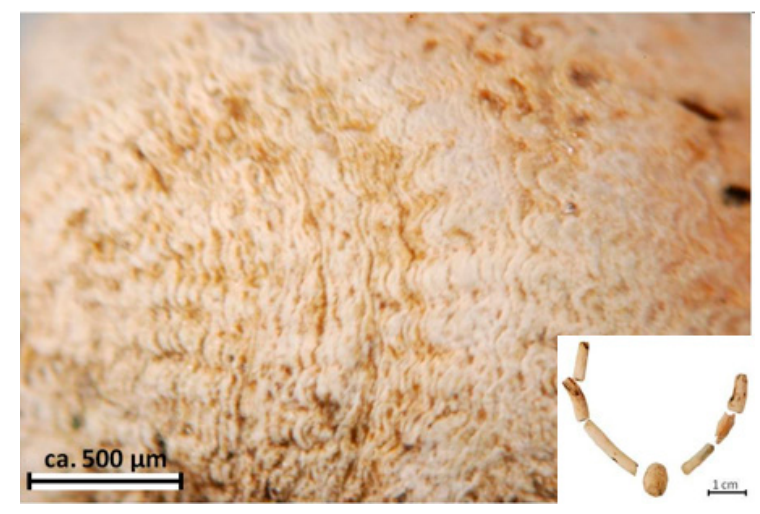

(e)

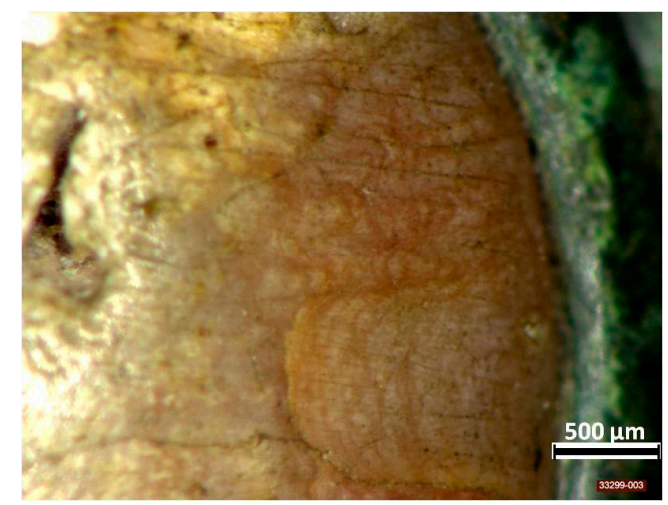

(f)

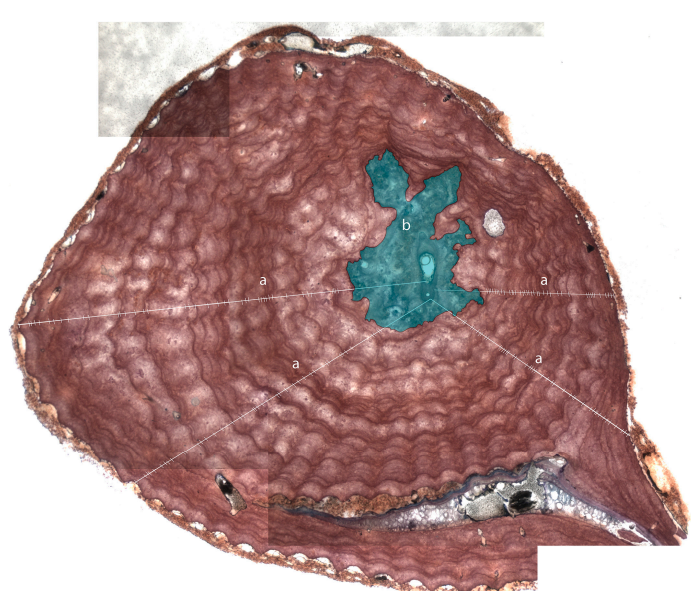

(g)

Figure 3. Surface structures of ancient corals and similarities with recent reference objects. (a) Inner side of three lamellae of a coral bead from a female grave in Ditzingen-Schöckingen (Landkreis Ludwigsburg). (b) Corallium rubrum from an area near Marseille with longitudinal crenulation covering the stem, resulting in a concentric, wavy structure in the cross section. (c) Belt chain from Bussy-le-Château (département Marne), showing three concentric features of more intense color than the pale center of the piece, indicating the medullar region of a cross-section of C. rubrum; see (Figure $3 g$ ). (d) Recent C. rubrum from the Strait of Messina also showing parts of faded color. (e) Coral bead from Tomb 122 of the Magdalenenberg tumulus; detail of Figure 2a. (f) Detail of a partially red area of a C. rubrum piece from Somme-Tourbe "la Bouvandeau" in the Champagne. (g) Section of a Corallium rubrum colony after decalcification and staining [47,53].

A comparison of the structural similarities of recent and archaeological corals, as shown in Figure 3, allows the identification of corals, even in the case of small studs.

The most characteristic structure of the C. rubrum skeleton can be seen both on the inner side of three lamellae of an originally egg-sized coral bead from a female grave in Ditzingen-Schöckingen (Landkreis Ludwigsburg) (Figure 3a), as well as on a recent C. rubrum stem from the Mediterranean Sea off Marseille (Figure 3b). This longitudinally-crenulated surface is a distinctive sign of C. rubrum $[1,3,4,13,17]$. As seen on the recent specimen, these grooves cause a wavy edge of the cross-section. The microscope picture of the belt chain from Bussy-le-Château (département Marne, France) (Figure 3c) shows a slightly lighter center of irregular shape surrounded by concentric structures indicating the medullar region of a cross-section of C. rubrum, as indicated by the grey area in Figure 3g. The specimen in Figure 3d demonstrated that recent corals from the Mediterranean Sea (from the Strait of Messina in this case) can also be partly uncolored. While the recent coral in Figure $3 b$ exhibits only a wavy edge in the cross-section, the coral beads from the already mentioned Tomb 122 of the Magdalenenberg tumulus in Baden-Württemberg (Figure 3e) and a small inlay of a shoe knob from Somme-Tourbe "la Bouvandeau" in the Champagne (Figure 3f) present a circular domain composed of concentric rings. The difference between these two lies in the surface structures: 
the Somme-Tourbe piece shows in a still colored area (on the right side of the photo) a conspicuous color banding. A similar annular domain can be seen on the Magdalenenberg piece, but not as a color banding, rather as small gaps. These concentric corrugated features correspond to the growth rings of a stained cross-section of C. rubrum, as shown on Figure $3 g[1,3,4,13,17,45,47,53]$. The examples from Ditzingen-Schöckingen (Figure 3a), Bussy-le-Château (Figure 3c) and especially from Somme-Tourbe (Figure 3f) illustrate a further interesting structural correlation: the more color that can be seen on an artifact, the more lustrous and smooth is the surface.

Larger and rounder shapes of modern C. rubrum usually derive from the sockets of a Corallium colony. In this case, the C. rubrum pieces are called "foam coral" because of their porous structure (see Figure 4a) [3].

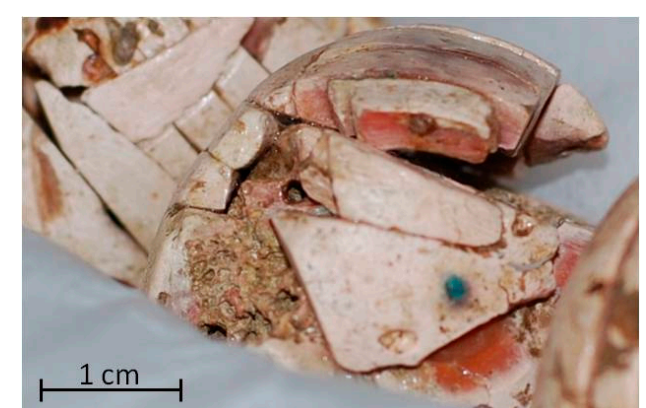

(a)

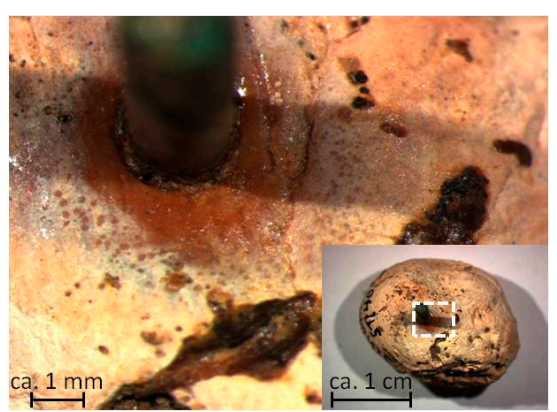

(b)

Figure 4. (a) Detail of the almost egg-sized coral bead from the female burial of Esslingen-Sirnau; see Figure 2d; (b) detail of another almost egg-sized coral bead from Ditzingen-Schöckingen, where a small red part around the bronze pin is visible.

\subsection{Remains of the Former Coloring}

Many archaeological pieces reveal still colored areas (Figures $3 a$ and 4), most often at formerly well-protected parts, as seen in Figure 4a (see also Figure 3a), where the lamellae of the egg-sized coral beads are still red on the sides, because other lamellae were originally attached. In most cases, the fading of the color progresses from the outside to the inside. Furthermore, coral is often still red at points that are in direct contact with metal, i.e., around rivets (Figure $4 \mathrm{~b}$ ) or at the edge of inlays (Figure 3f).

\subsection{Identification of Ancient Corals: Case Studies}

The following case studies were chosen to demonstrate how the optical and Raman investigations of today light colored biominerals on archaeological artifacts help to inform about the nature of the materials used to decorate the objects in ancient times.

The analyses of the three light colored pieces of a small fibula (Figure 5) from a rich female grave of the second half of the fifth century BC from Schwieberdingen "Wartbiegel" in northern Baden-Württemberg in Germany yielded interesting results concerning the usage of different materials on one artifact, the connections to long distance trade objects and the social structures at that time. Nowadays, the preservation conditions and colors of the three pieces on this very small (only $3 \mathrm{~cm}$ long) iron fibula differ from each other. The small bead at the reversed foot of the fibula is almost completely covered by layers of brown corrosion material and has an irregularly-formed surface. The largest piece on the bow at the center of the fibula is placed on a thin gold foil and is fixed by a small golden rivet. Although this cabochon is partially broken and the surface is also irregular, it still has pinkish and orange hues. The small bead on the spring in the front of the fibula has a light and intact surface texture, but with a few small brown spots of corrosion products. The spectra of the pieces from the foot and bow show features of calcite with a $\left(\mathrm{CO}_{3}\right)^{2-}$ main band at $1086 \mathrm{~cm}^{-1}$ and two minor bands at 282 and $713 \mathrm{~cm}^{-1}$. The wavenumber position is only slightly higher than that of biogenic 
calcite and is in the lower region of the expected value for HMC as incorporated in modern C. rubrum (see Figure $1 ;[18,50,51])$. The characteristic $v_{1}$ and $v_{2}$ bands, representing the unmethylated polyenic pigments at 1518 and $1130 \mathrm{~cm}^{-1}$, of the still orange colored bead from the bow are very intense and as high as the $\left(\mathrm{CO}_{3}\right)^{2-}$ band, even with a 632.8-nm excitation. Two more pigment bands at 1020 and $1294 \mathrm{~cm}^{-1}$ are visible. The combination of a broad calcite band together with intense pigment peaks offers a high probability of C. rubrum.

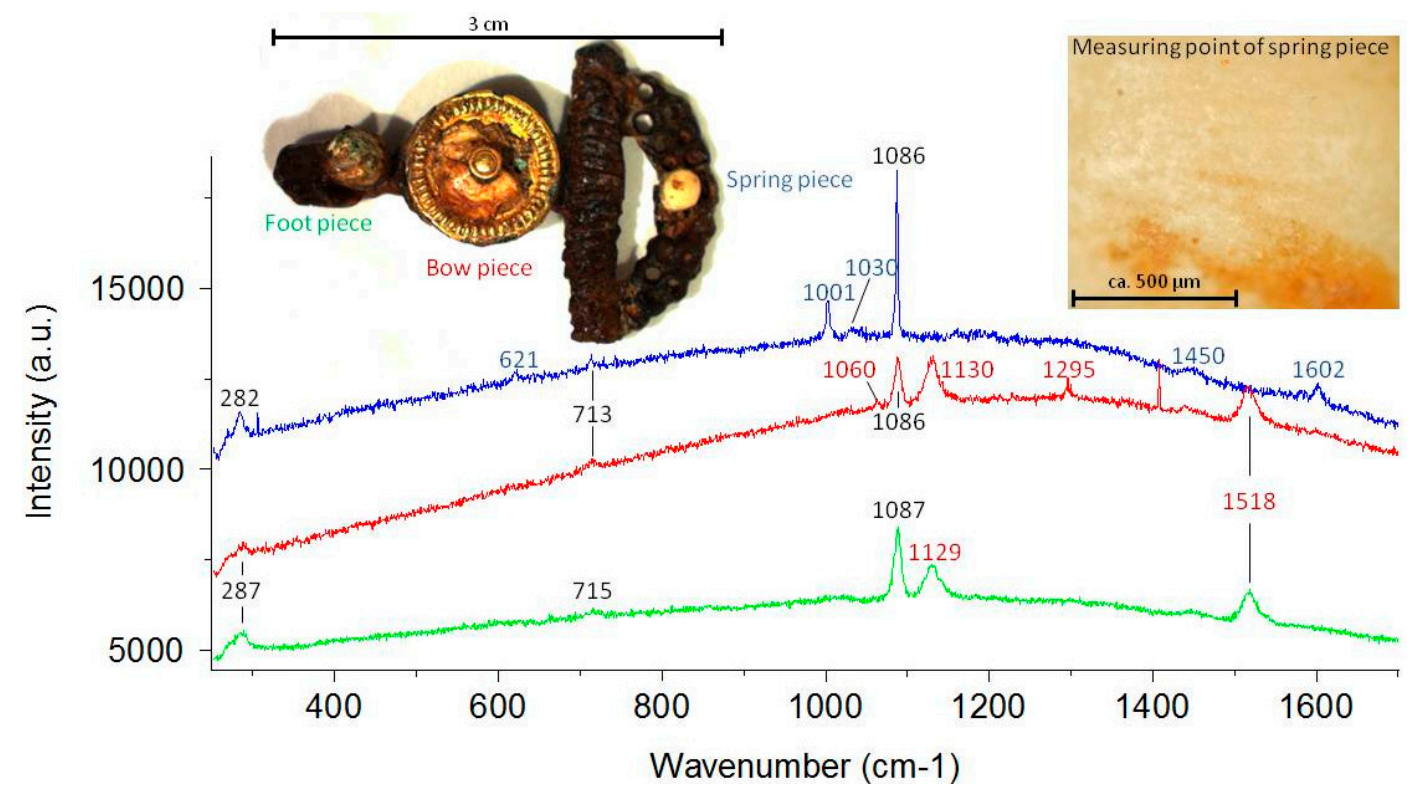

Figure 5. Raman spectra of the three light colored pieces of the fibula from Schwieberdingen "Wartbiegel", taken with $632.8 \mathrm{~nm}$. The pieces from the foot (green) and from the bow (red) of the fibula clearly show calcite and polyene features, indicating C. rubrum. In contrast, the piece from the spring of the fibula (blue) yields a spectrum with a sharp $\mathrm{CaCO}_{3}$ band at $1086 \mathrm{~cm}^{-1}$, but no pigment bands.

In contrast, the piece from the spring of the fibula yielded a spectrum with a sharp $v_{1}$ calcite peak at $1086 \mathrm{~cm}^{-1}$, a band at $283 \mathrm{~cm}^{-1}$, assigned to the rotational $\left(E_{\mathrm{g}}\right)$ mode, and a weak band at $713 \mathrm{~cm}^{-1}$ of the internal $E_{g}$ corresponding to the in-plane bending modes $\left(v_{4}\right)$, but without any pigment-related features.

As mentioned above, the smaller full width at half maximum (FWHM) of the calcium carbonate band at $1086 \mathrm{~cm}^{-1}$ of the spring bead in comparison to the other two pieces may result in less $\mathrm{MgCO}_{3}[18,51]$, which is, together with the pigment features, characteristic for C. rubrum. Therefore, the spring bead is likely to have been made of an almost pure, non-colored calcite, maybe marble or some kind of shell. The dense structure of the material underlines this suggestion (Figure 5, top right).

While the Raman measurements of the small iron fibula from Schwieberdingen "Wartbiegel" demonstrated that sometimes, coral was combined with other materials on one object, another iron fibula of the same type, only with a bronze sheet instead of a gold foil, is an example that even one single pearl could be made out of two different materials. This piece was also found in a rich female burial and dates to the same period (450-400 BC), but this time, $c a .90 \mathrm{~km}$ further northwest in Ilvesheim "Weingärten" near Mannheim.

Of the original seven decorative elements of the iron fibula, the remaining three have been investigated by Raman spectroscopy. The bead on the foot (Figure 6) already showed typical optical signs of C. rubrum, which could be confirmed by the Raman spectrum. The bands labeled in red in Figure 6 also indicate that this pearl had originally been red. 


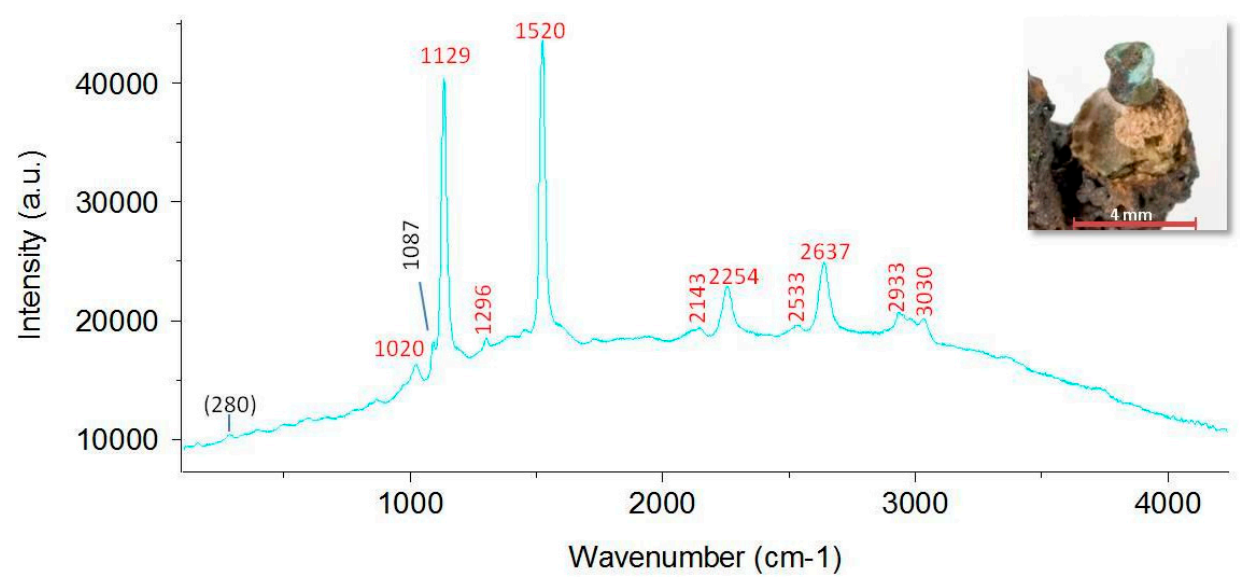

Figure 6. Ilvesheim "Weingärten"; Raman spectrum of foot bead of small iron fibula. The characteristic $v_{1}$ and $v_{2}$ frequencies of the pigments at 1520 and $1129 \mathrm{~cm}^{-1}$ are still very intense. Red = pigments; black $=$ calcite.

Today, the bead on the spring of the fibula has a reddish-brown color. The material used (Figure 7) could not be identified yet, since the obtained spectrum neither corresponds to calcium carbonates, like corals and mollusks, nor to any kind of apatite-containing material, like bone or ivory. The presence of amorphous carbon in the region $1580-1600 \mathrm{~cm}^{-1}$ with a smaller band at about $1458 \mathrm{~cm}^{-1}$ indicates a contamination or residues of organic material. This piece expands the range of materials and shades employed in Iron Age jewelry, since it can be assumed that the original hue came close to the current one and that it looked neither like ivory nor like coral.

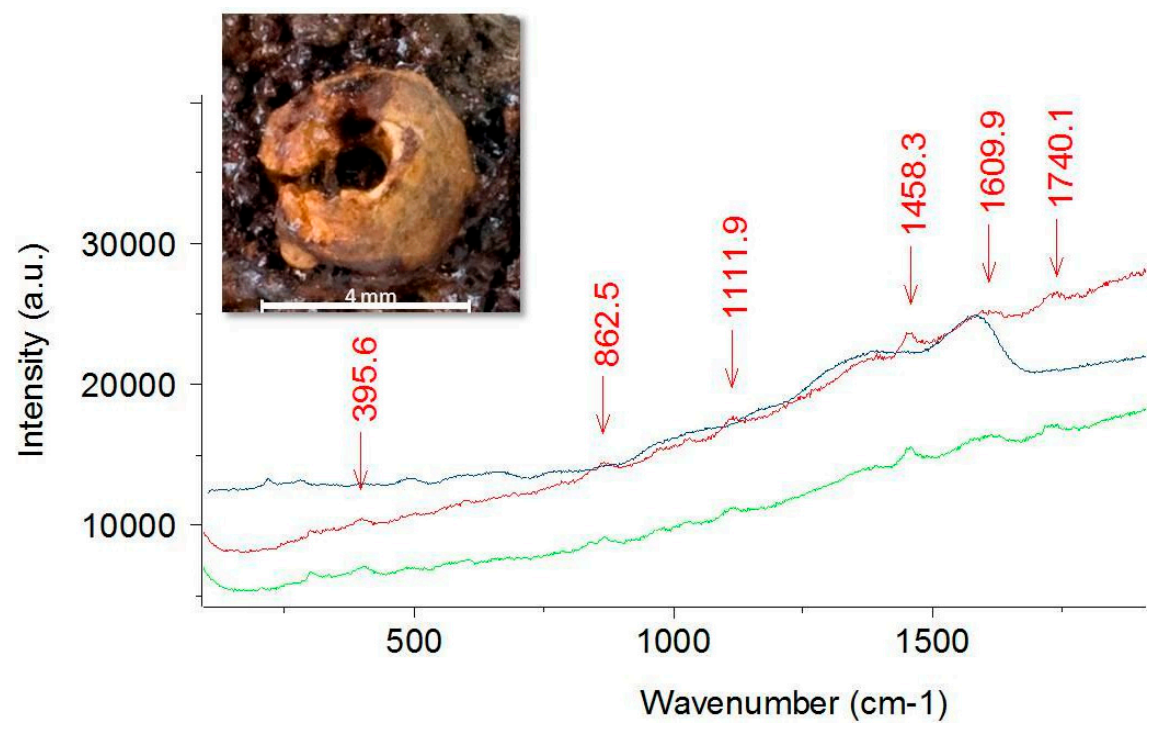

Figure 7. Ilvesheim "Weingärten"; Raman spectrum of the spring bead of the small iron fibula (see Figure 8). The presence of amorphous carbon in the region $1580-1600 \mathrm{~cm}^{-1}$ with a smaller band at about $1340 \mathrm{~cm}^{-1}$ indicates a contamination or residues of organic material. 


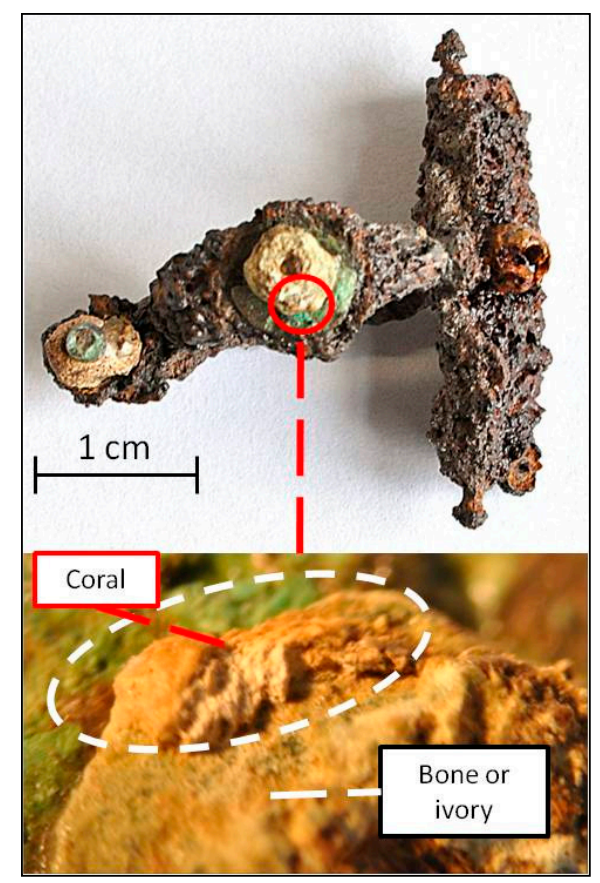

Figure 8. Small iron fibula from Ilvesheim "Weingärten". The picture below shows the detail of the bead on the bow with the microscopic coral piece adhering to a base made of apatite-containing material.

Particularly surprising were the spectra of the only 0.6-cm small bead of the bow (Figure 8): first, the material was identified as coral (Figure 9), but then, however, further measurements of the supposedly same piece surprisingly yielded several spectra of apatite from different areas of the material (Figure 10), which is generally associated with bone or ivory. A subsequent microscopic examination revealed an extremely small amount of coral adhering to a base made of apatite-containing material (Figure 8, below). However, due to poor preservation, it cannot be clarified whether a lack of coral had to be concealed or whether a red-white contrast was intended.

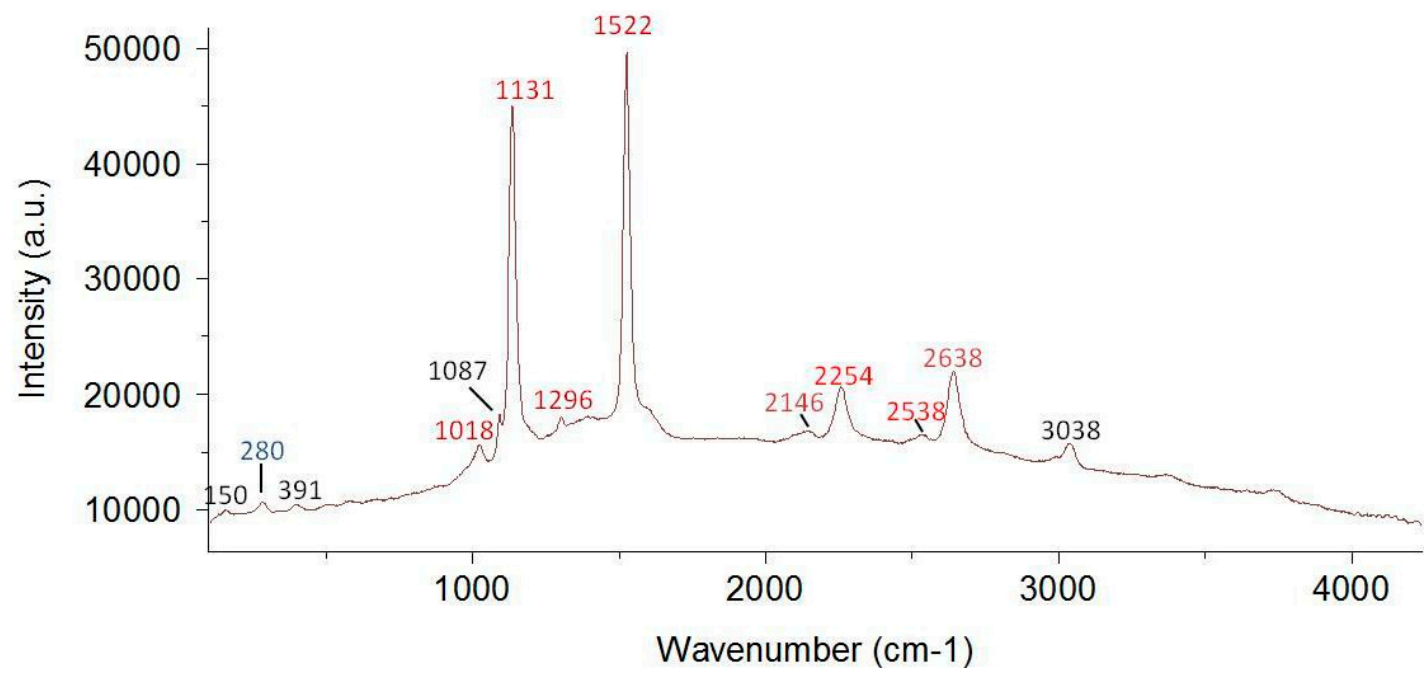

Figure 9. Ilvesheim "Weingärten"; Raman spectrum of the bow bead (see Figure 8). The characteristic $v_{1}$ and $v_{2}$ frequencies of the pigments at 1522 and $1131 \mathrm{~cm}^{-1}$ are still very intense. Red = pigments; black $=$ calcite. 


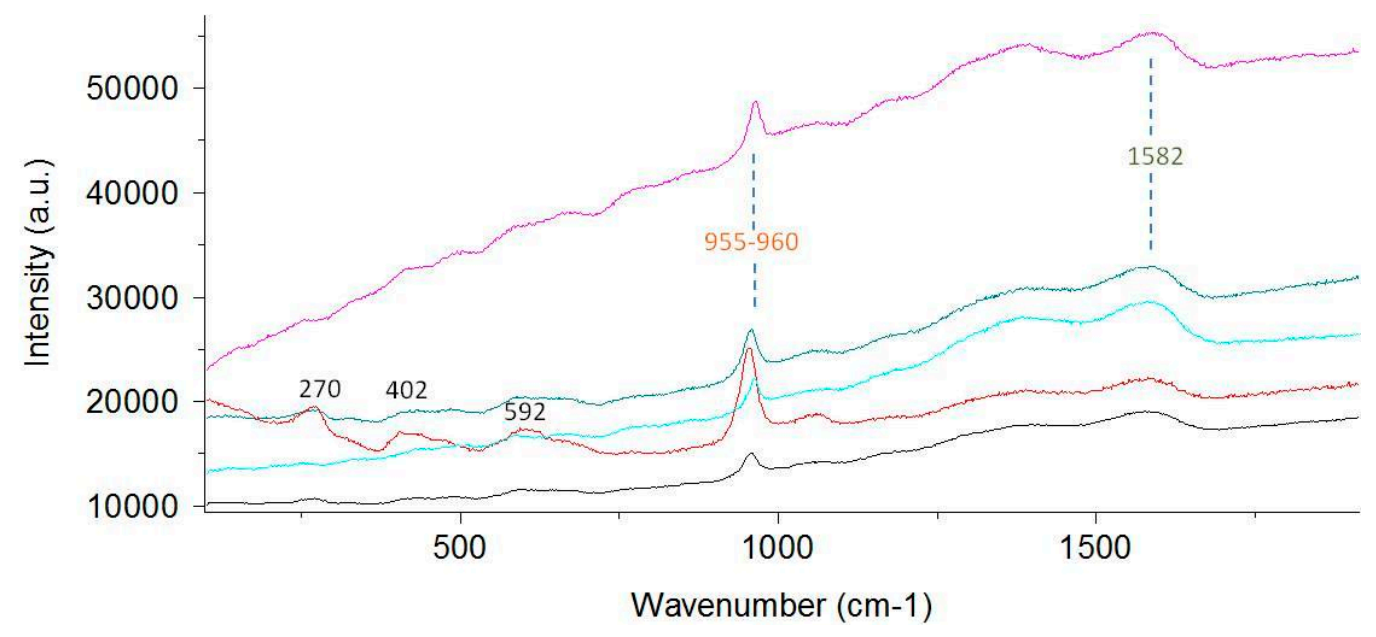

Figure 10. Ilvesheim "Weingärten"; Raman spectrum of the bow bead (see Figure 11) with apatite at 955-960 $\mathrm{cm}^{-1}$ and amorphous carbon.

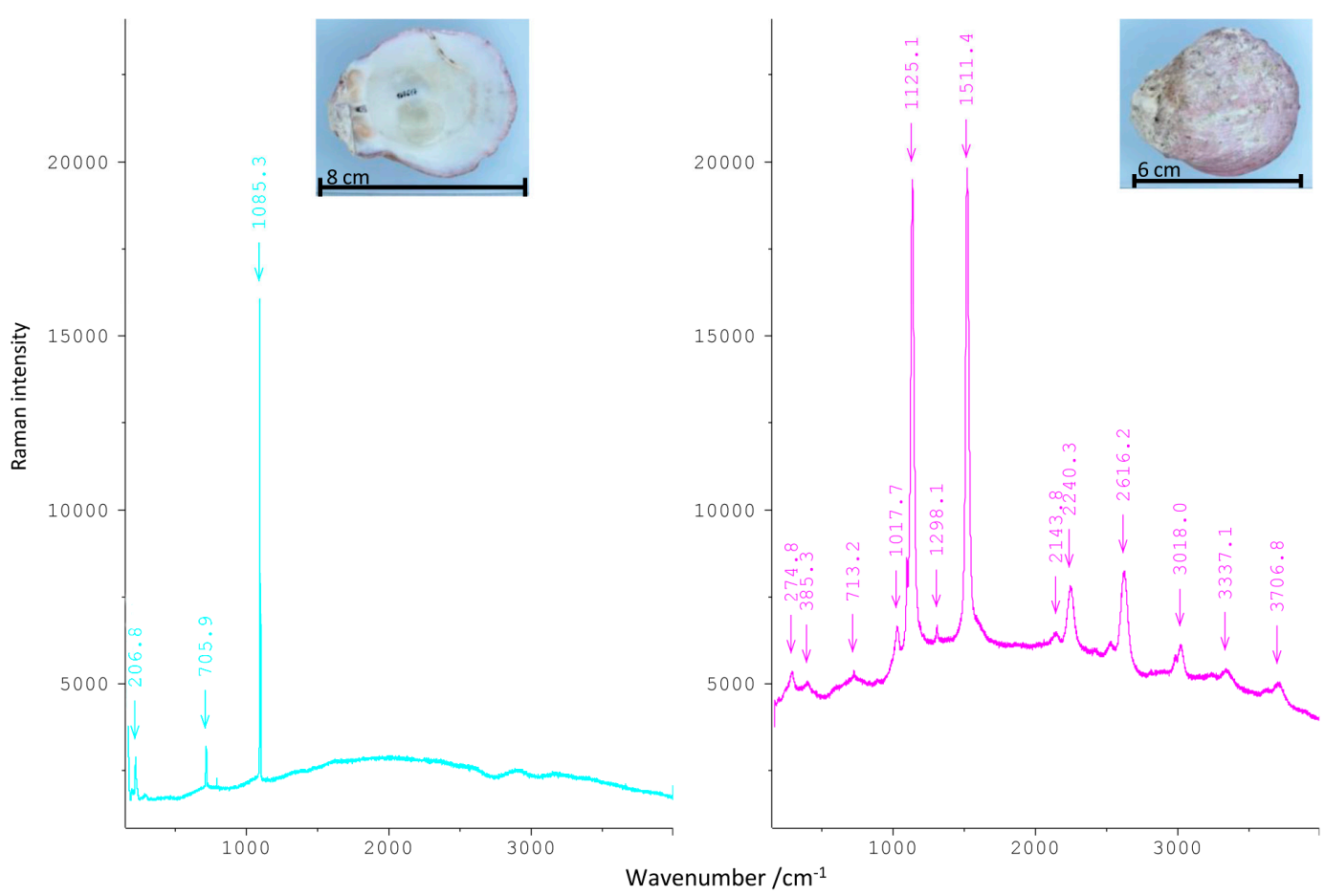

Figure 11. Raman spectra of Spondylus gaederopus from Morea, Greece, taken with $532 \mathrm{~nm}$ (diode). Left: white interior of shell with aragonite bands at 154, 207, 706 and a narrow $\left(\mathrm{CO}_{3}\right)^{2-}$ peak at $1085 \mathrm{~cm}^{-1}$, but no polyenes. Right: colored exterior showing the polyene main bands at 1125 and $1511 \mathrm{~cm}^{-1}$ and several combinations and overtone bands, as well as calcite features at 275 and $713 \mathrm{~cm}^{-1}$.

\subsection{Identification Methodology}

Methodologically, these previous findings on the structure and color of archaeological and recent C. rubrum artifacts and other biominerals (see [54]) can be joined together in the form of a non-destructive multi-stage approach to identify red corals and light colored biominerals with emphasis on optical examination, digital microscopy and Raman spectroscopy with a laboratory instrument or a portable one.

As Figure 12 illustrates, the fastest and easiest way to identify C. rubrum is the detection of characteristic structures by optical examination. In most cases, the surface shows significant features of 
one or the other material. As already mentioned above, the most characteristic structure of C. rubrum is the longitudinal crenulation of the surface that can also be seen in the perpendicular section as concentric rings around the medullar region (see Figure 3).

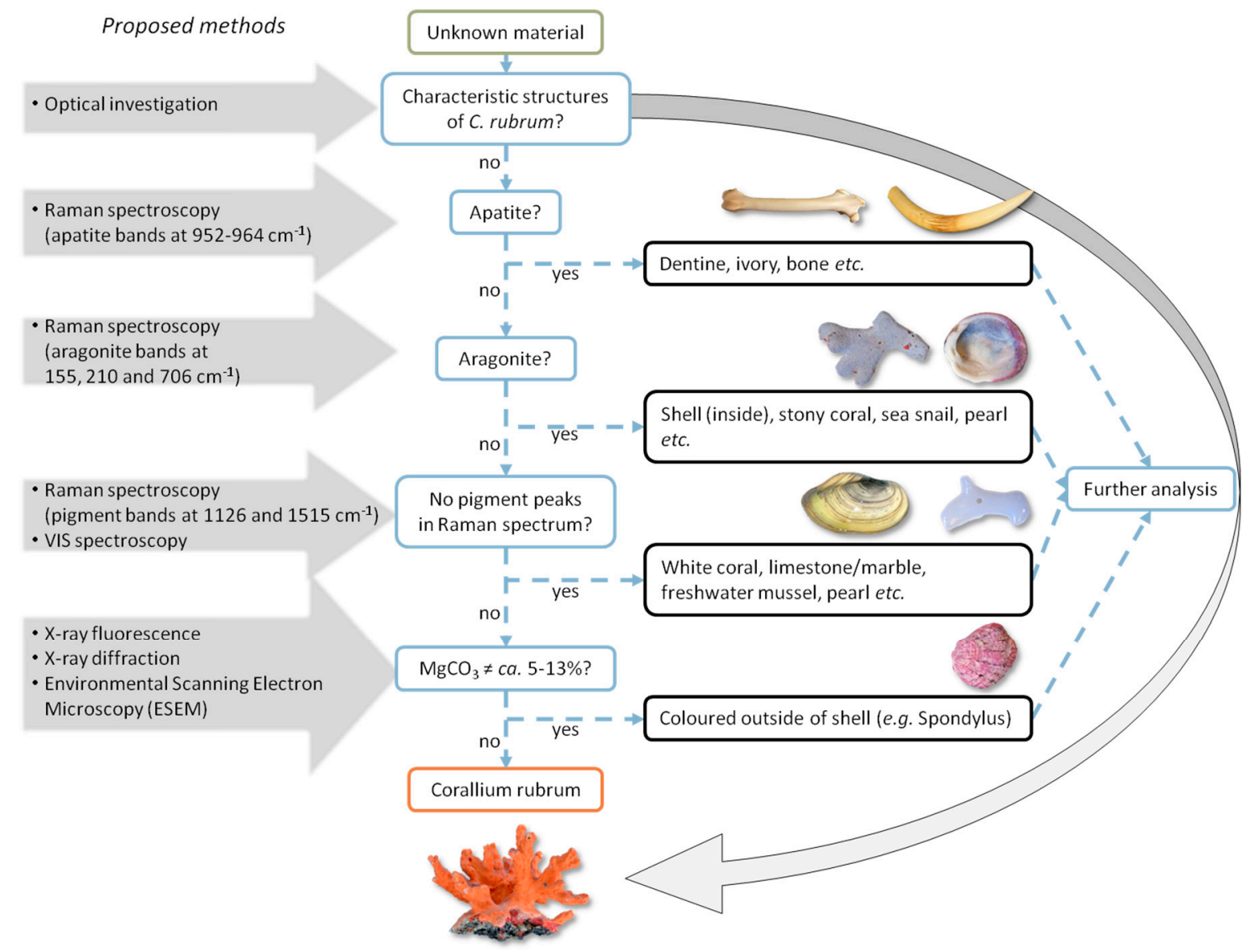

Figure 12. Protocol for non-invasive identification of Corallium rubrum.

If an optical investigation fails, the identification of organic pigments and calcite by Raman spectroscopy limits the group of possible materials from the adjacent seas that were accessible at that time to C. rubrum and the colored parts of some big shells, like Spondylus. Since Octocorals, like C. rubrum, consist of an HMC, unlike mollusks, this shift could (theoretically) function as an indicator for material identification (see the discussion below).

As a final step, if a patina of metal oxide covers the surface or the material does not allow a Raman spectroscopic investigation, complementary mobile analytical techniques can be used. The combination of XRF and XRD together with environmental scanning electron microscopy (ESEM) or micro-CT enables the recognition of the (micro-)structural and chemical features of even strongly-fluorescent objects. ESEM is a non-invasive technique, which allows the observation of the microstructural features preserved in the archaeological remains and to compare this with the microstructural data of Corallium and other organisms.

\subsection{Summarized Results}

Besides the recent and archaeological reference objects, 72 artifacts, decorated with a total of 263 pieces of light colored biominerals, were optically and Raman spectroscopically investigated in order to determine the used materials.

It has to be noted that the evaluation of Table 2 is not statistically significant. The high number of 45 unidentified pieces due to patina derives from the analysis of only four artifacts from one 
location. Among these objects, one fibula was ornamented with 109 pieces. If these pieces had not been analyzed, the proportion of red coral after investigation would have risen to $77.5 \%$. Beside these statistical notes, the results demonstrate the need for further studies: a correction of the material reported in the literature or at least a clarification for uncertain materials could be made for 25 out of 72 archaeological objects with light colored inlays (for an overview, including archaeological reference objects, see Table S1).

Table 2. Non-representative list of investigated decorative elements showing the previously-supposed material, the specific result of our examination and, finally, the interpretation of the data in terms of the most probable original material. The data consist of Raman spectroscopic and optical investigations.

\begin{tabular}{|c|c|c|c|}
\hline Number of Pieces ${ }^{1}$ & Previous Material & Status & New Material \\
\hline 169 & Red coral & approved & Red coral \\
\hline \multicolumn{4}{|c|}{ Proportion of approved materials: $64.3 \%$} \\
\hline 5 & Previously unspecified & clarification & Red coral \\
\hline 1 & Amber or coral & clarification & Red coral \\
\hline 1 & Not specified & clarification & Enamel \\
\hline 4 & Amber or coral & clarification & Not coral, possibly amber \\
\hline \multicolumn{4}{|c|}{ Proportion of clarifications: $4.1 \%$} \\
\hline 5 & Red coral & $\begin{array}{l}\text { partial specification } \\
\text { of substance }\end{array}$ & I.g. some kind of carbonate \\
\hline \multicolumn{4}{|c|}{ Proportion of partial specifications ${ }^{2}: 1.9 \%$} \\
\hline 1 & "White paste" & different material & Red coral \\
\hline 2 & Bone & different material & Red coral \\
\hline 2 & Bronze & different material & Red coral \\
\hline 7 & Red coral & different material & White coral or shell \\
\hline 1 & Amber & different material & White coral or shell \\
\hline 3 & Red coral & different material & Ivory (or bone) \\
\hline 4 & Red coral & different material & Enamel \\
\hline 7 & Red coral & different material & Unidentified material \\
\hline \multicolumn{4}{|c|}{ Proportion of changed material interpretations: $10.3 \%$} \\
\hline 45 & Red coral & $\begin{array}{l}\text { No results due } \\
\text { to patina }\end{array}$ & Unknown \\
\hline \multicolumn{4}{|c|}{ Proportion of pieces without result due to patina ${ }^{3}: 17.1 \%$} \\
\hline 6 & $\begin{array}{l}\text { Red coral, not } \\
\text { specified, bone }\end{array}$ & $\begin{array}{l}\text { No signal, only } \\
\text { fluorescence }\end{array}$ & Unknown \\
\hline \multicolumn{4}{|c|}{ Proportion of pieces without result due to fluorescence: $2.3 \%$} \\
\hline \multicolumn{4}{|l|}{ Total: 263} \\
\hline \multicolumn{4}{|c|}{ Proportion of red coral after investigations: $68.4 \%$} \\
\hline
\end{tabular}

1 "Pieces" refers to the single segments of a coral ornament, which can number several hundred for one single object, like a helmet or fibula; ${ }^{2}$ red coral was supposed, but the quality of the spectra was too poor to positively approve it; ${ }^{3}$ they originate from one single location with one fibula, decorated with 109 supposed coral pieces.

\section{Discussion}

Although an attribution to or an exclusion of C. rubrum is successful in most cases, some challenges in terms of material determination need to be addressed in order to indicate the scope of further studies.

\subsection{Challenges of Optical Identification}

Archaeological biominerals are subjected to diagenetic alterations, which can hamper the identification of red coral on archaeological artifacts. Archaeological shells may show a lamellar surface structure that resembles that of C. rubrum. Especially for small pieces like ground or polished 
studs displaying such surface features, a distinction between mollusks and corals based on the surface morphology may be very difficult, as the detail of the Iron Age shell from Saint-Hilaire-le-Grand in the Champagne region in France shows in Figure 13 (see also Figure 3e). However, in comparison to the coral pieces, mollusks can still have characteristically shiny nacreous parts. Furthermore, the typical layered shell structure differs from those of corals, because these layers are not spherical, but rather horizontal and have a much larger diameter compared to the crenulated surface of C. rubrum.

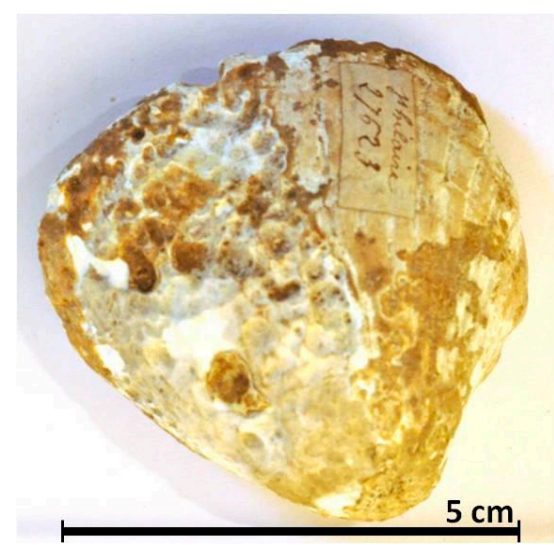

(a)

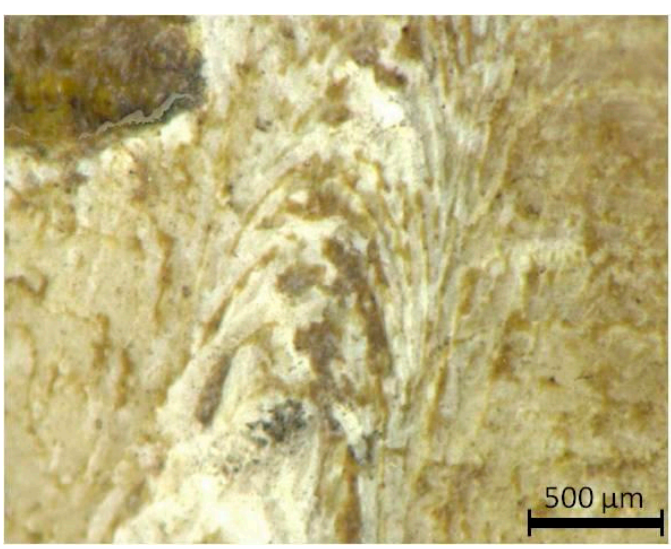

(b)

Figure 13. Iron Age shell from Saint-Hilaire-le-Grand in the Champagne region in France (a) and a microscopic image (b) of the structural features.

\subsection{Possibilities and Limitations of Raman Spectroscopy for the Identification of C. rubrum}

In most cases, Raman spectroscopy yields good results to distinguish between different biominerals, but it is still very hard or almost impossible at the moment to differentiate between calcitic colored shells and C. rubrum.

Figure 14 illustrates the direct correlation between color and the intensity of Raman bands associated with the red pigment. Measurements of a small white spot on an otherwise red piece of C. rubrum from the Mediterranean Sea with a 487.9-nm $\mathrm{Ar}^{+}$-laser excitation, which is particularly sensitive to colorants, obtained almost no indications of polyenes at around 1130 and $1520 \mathrm{~cm}^{-1}$, while the surrounding red area yielded a typical spectrum for $C$. rubrum with intense polyene bands and a small one for $\left(\mathrm{CO}_{3}\right)^{2-}$ at about $1086 \mathrm{~cm}^{-1}$. The HMC features in the lower frequency region were too small to be observed by 488-nm excitation without clipping. The Raman spectrum for the light red colored periphery of the white spot shows very small bands at 1134 and $1526 \mathrm{~cm}^{-1}$, characteristic of the organic colorant.

The same effect can be observed on shells (Figure 11), where the inner side of the shell is mostly white and yields a spectrum of almost pure aragonite with bands at 154, 207, 706 and $1085 \mathrm{~cm}^{-1}$, respectively; $E_{g, e x t}$ modes for the two first bands $(T, L)$ and $E_{g, \text { int }}\left(v_{4}\right)$ and $A_{1 g \text {,int }}\left(v_{1}\right)$ modes for the following. In contrast, the spectrum of the purple colored exterior shows calcitic features at 275 and $713 \mathrm{~cm}^{-1}$. The $v_{1}$ and $v_{2}$ frequencies at 1511 and $1125 \mathrm{~cm}^{-1}$ of the colorants are so intense that the $\left(\mathrm{CO}_{3}\right)^{2-}$ band is superimposed. Furthermore, several combinations and overtone bands are visible.

A comparison of the spectra from colored and uncolored corals and mollusks (Figures 11 and 14) suggests that the main bandwidth of $\mathrm{CaCO}_{3}$ at $1086 \mathrm{~cm}^{-1}$ is smaller, when no band characteristic of the colorant is detected. In addition, the $\mathrm{CaCO}_{3}$ band of mollusks, and especially of sea snails at around $1086 \mathrm{~cm}^{-1}$, seems to be usually sharper than the corresponding band of corals, even if the shells are also colored. The larger carbonate band in corals may be caused by the partial substitution (less than $10 \mathrm{~mol} \%$ ) of $\mathrm{Mg}^{2+}$ for $\mathrm{Ca}^{2+}$ in the calcite, causing a static positional disorder, as described by Urmos et al. [18]. 


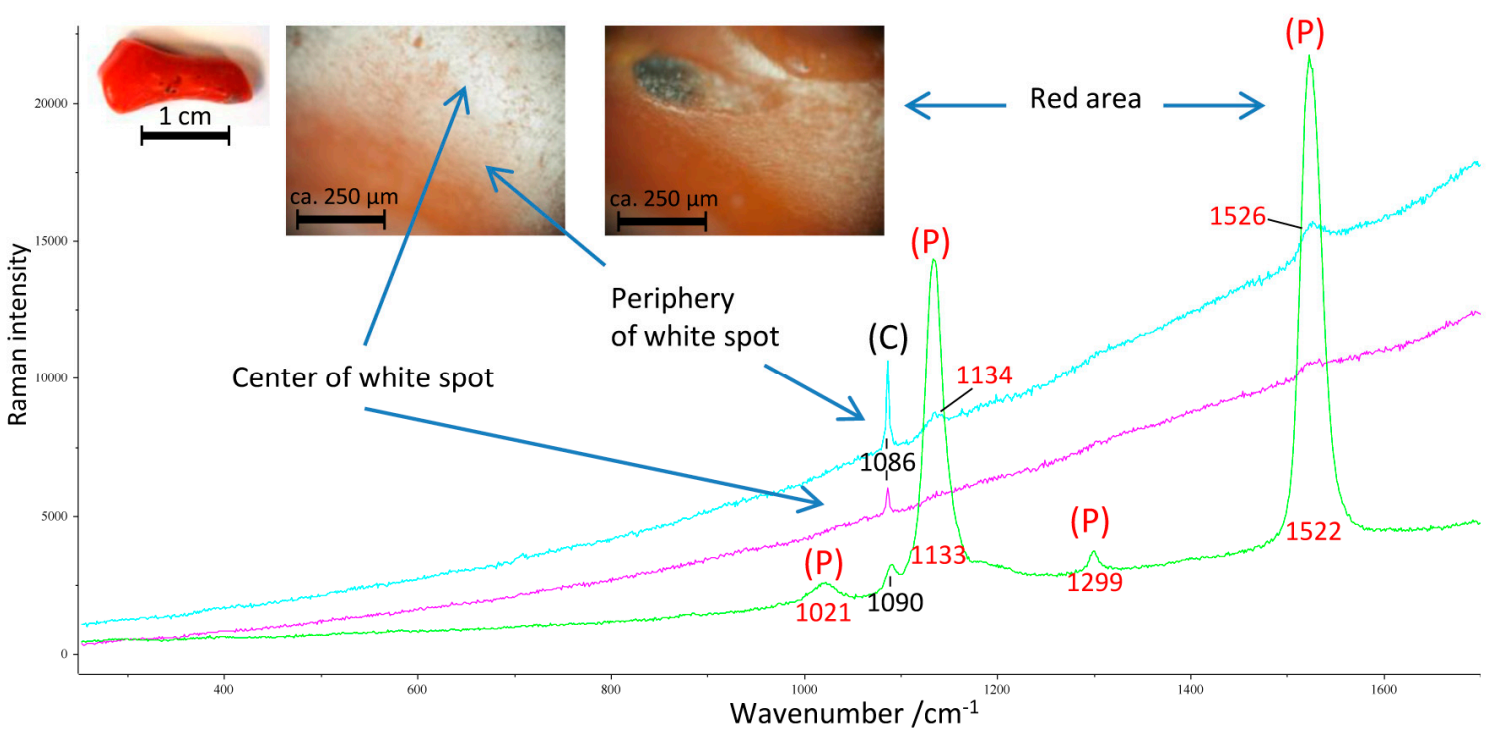

Figure 14. Comparison of Raman spectra from a white spot and from a red part of a single branch of Corallium rubrum from the Mediterranean Sea, all taken with $487.9 \mathrm{~nm}\left(\mathrm{Ar}^{+}\right)$; $(\mathrm{P})$ stands for polyenes and (C) for calcite.

The identification of unknown archaeological biominerals can be hampered due to their high fluorescence and poor signal to noise ratio. However, the Raman spectra of only six of a total of 263 analyzed decoration materials could not be evaluated due to high fluorescence. As this corresponds to a very low proportion of the analyzed artifacts (only 2.3\%), special methods to reduce the fluorescence problem were not applied. Thanks to the resonant Raman obtained with coral colorants using specific laser wavelength, its detection is achievable over the fluorescence signal even with the very low remaining contents. Further studies will allow determining if for these six artifacts, the absence of a Raman signature from the colorant is due to deep degradation or the use of another material than coral.

\subsection{Hypotheses for the Loss of Color of Archaeological Corals}

The loss of color of archaeological corals is probably linked to diagenetic alterations occurring over time due to various processes, depending on the environmental conditions (temperature, humidity, acidity and composition of the soil, activity of microorganisms), which were very well studied for other biominerals, like bones or teeth (e.g., [55]). This raises the question of where the colorants are actually located. To our knowledge, localization of colorants has not yet been explored in detail. Systematic optical examination of ancient corals allows several assumptions about the encapsulation of the polyenes within the axial skeleton and the process of bleaching.

A first hypothesis addresses the organic diagenesis. As demonstrated by Figures $3 a$ and 4 , the pieces that are today light colored were originally as red as modern precious corals. The loss of color usually begins at the most exposed point of the piece and initially spreads along the surface until it penetrates into the internal structure of the object. The characteristic crenulations of the growth rings on the perpendicular sections of archaeological corals appear very often and look like the concentric growth rings of an annular domain with stained organic matter (OM), as in Figure 3g. However, in contrast to modern stained coral, the archaeological pieces do not only exhibit color differences due to partial fading, like on the Somme-Tourbe piece (Figure 3f), sometimes even small gaps between the concentric rings appear, as seen on the Magdalenenberg piece (Figure 3e). Vielzeuf et al. [13] have shown that "the growth rings are revealed by the cyclic variation of organic matter $(\mathrm{OM})$ and $\mathrm{Mg} / \mathrm{Ca}$ ratio". The loss of color seems to be accompanied by a change in ultrastructure, which leads us to the hypothesis that these gaps, which are normally not visible on modern corals without any treatment, may be caused by the decay of the OM by time, resulting in a fissured structure in the shape of the 
modern corals after coloration treatment. Nevertheless, there still is enough colorant left, perhaps in the sclerites, to obtain Raman bands under resonant conditions.

As a further hypothesis, the loss of color may be related to the diagenetic processes of the HMC. Concerning coral diagenesis, some work was done on aragonitic corals to study the effect of diagenesis on paleoclimate reconstruction [56]. Dissolution of primary coral aragonite, infilling of skeletal pores and recrystallization of aragonite to calcite were observed. For calcitic corals, dissolution of HMC (leaching of Mg) and stabilization as LMC is thinkable. The bleaching could also be related to this process.

Finally, human activities, such as an intentional bleaching, e.g., by boiling, could be the cause. However, this hypothesis appears to be not very resilient. First, it seems rather unreasonable to import corals over such a long distance only to change the color until they look like ordinary bone or tooth, especially not at a time when vivid colors were rare. Secondly, there are sometimes still red areas visible on the front side of the inlays (see Figure 3f), mostly on the edges of inlays, next to the surrounding metal, which seems to have prevented fading. Red areas around rivets, as seen in Figure $3 \mathrm{~h}$, can be observed very often, as well. Metals can have an antibacterial effect (e.g., $\mathrm{Cu}$ in bronze). The authors have observed an influence of the presence of heavy metals, including copper, on the degradation of the microstructure of archaeological bone samples due to microbial activity [57].

Future works aim at a better understanding of the interaction of the organic matrix or the mineral part with the coloring components of the corals, of diagenetic alterations of archaeological corals in order to understand the alteration processes resulting in a loss of color and a change of the surface structure.

\subsection{Archaeological Implications}

We are aware of the fact that our method would not sufficiently meet the standards for the identification of marine ecology, Earth science, etc. However, for Iron Age research, where it can be assumed from the archaeological record that the marine material most probably came from the Mediterranean Sea or from the Atlantic and the Northern seaboard, the range of potential raw material is considerably smaller, and many other species can be ruled out by the simple fact that they do not occur near the European coastline.

The analyses of the beads on the fibula from Schwieberdingen (see Figure 5) demonstrate that different color accents were used to decorate one single object. Prior to these studies allowing the detection of colorants in already faded biomineral, it has been a matter of controversy whether only red colored corals were used for Iron Age ornaments or if also light colored materials were employed and to what extent (e.g., [58-61]). Furthermore, the proof of $C$. rubrum for this fibula changes the interpretation of the whole burial. Besides the small gold foil, the corals (there are two more fibulae with light colored beads) are the only precious material among the grave goods, and they document connections to Mediterranean trade networks. These two aspects in turn raise the status of the buried person.

From the archaeological point of view, the identification of the used material is very important because the evidence of its presence may change the whole interpretation of an archaeological object or site. In comparison to the trade route models derived for other Mediterranean goods, the distribution pattern of (supposed) coral finds appears to be more dynamic, indicating trade routes in a higher spatial resolution and distributional "hot spots". They also play a crucial role in the reconstruction of social structures. As an indicator of prestige, the proof of coral in a grave shifts the notional social position of the deceased. Furthermore, there has been a dispute if red corals were used together with red glass, which became popular during the third century BC, to decorate objects. Since the corals appear almost white today and it would not make much sense to use two different red materials, it was assumed that they were white in the first place. Our proof of polyenes in the case of the fibula of Gäufelden-Nebringen (Landkreis Böblingen), Grave 17 (see Table S1), argues against this assumption. 


\section{Conclusions}

This study showed that analytical examinations of light colored biominerals can provide key information on the inlay materials of Iron Age precious objects. A combination of optical investigations and Raman spectroscopy allow a reliable identification of Corallium rubrum with respect to bone and ivory. Because Raman spectroscopy is non-invasive, requiring only a low amount of material without sampling or sample preparation, and allowing short measurement times, it is a very efficient method, especially for analyzing archaeological materials and/or gemstones [62,63]. In addition, thanks to the availability of portable instruments, measurements can be performed on site in museums. Foremost, it enables a limitation or even identification of the most eligible materials. Raman spectroscopy possesses a special benefit for the study of colored biominerals. Based on the study of 95 archaeological artifacts and 41 recent corals and mollusks, the non-invasive identification procedure was established and successfully tested.

The distinction between C. rubrum and the calcitic outer part of a colored Spondylus shell by Raman spectroscopy can sometimes be effected on the basis of Mg contents (HMC in C. rubrum and LMC in Spondylus), and the smaller bandwidth of the $v_{1}$ carbonate band of mollusks at around $1086 \mathrm{~cm}^{-1}$ can serve as an indication. However, due to the substitution of $\mathrm{Mg}$ by time, this feature is not fully reliable. If also an optical investigation yields no characteristic structural features because of a processed surface, the identification procedure needs to be completed by additional analyses by XRF, XRD, ESEM or micro-CT that allow the determination of the $\mathrm{MgCO}_{3}$ content and the microstructure of the material.

Nevertheless, much new information of archaeological relevance can be gained from a systematic study of Iron Age inlays using the newly-established identification procedure. This study reveals a previously unsuspected variety of materials and colors. This changes our picture of relatively uniform costumes to a more creative and individual style, possibly depending on the available resources. In the context of the whole grave or, rather, the deceased, the identification of a variety of employed materials helps to refine the scales of social distinction by conspicuous consumption of prestige goods. A large fibula, but with inlays made from ordinary bone, for example, may not have been as valuable as a smaller one, but with exotic red corals. In times when bright colors usually were rare, corals must have been like signal lights of social status. Finally, on a macro-sociological level, a reliable approximation of the extent of coral use enables a mapping of trade routes and centers of distribution and consumption to gain a better understanding of the trade, communication and social structure of the Iron Age.

The same kind of procedure can also be adapted to other equivalent biominerals of archaeological relevance. Therefore, the full potential of the combination of the field of biomineral and biomineralization study and archaeology still needs to be exploited. Many new interesting results are expected from such studies to provide further information on the use of these materials in past societies and ancient ways of life.

Furthermore, future research work is planned focusing on a better understanding of the bleaching processes in archaeological red corals. This requires an improved knowledge of the colorant nature and its interaction with the coral organic and mineral part, as well as an in-depth study of diagenetic changes occurring in archaeological corals over time.

Supplementary Materials: The following are available online at www.mdpi.com/2075-163X/6/2/56/s1, Table S1: List of objects from archaeological contexts that have been analyzed by Raman spectroscopy, Table S2: List of used Raman spectroscopes with their settings and the amount of measurements.

Acknowledgments: The authors wish to thank the reviewers and the editor for their insightful comments and suggestions, as well as Daniel Vielzeuf (CINaM (Centre Interdisciplinaire de Nanoscience de Marseille)) for his friendly instructions. Furthermore, our thanks go to the following museums and research institutes for their valuable contribution to this work by providing their objects: Archäologisches Landesmuseum Baden-Württemberg, Zentrales Fundarchiv Rastatt, Badisches Landesmuseum Karlsruhe, Institute for Gemstone Research Mainz and Idar-Oberstein, Landesmuseum Mainz, Landesmuseum Württemberg Stuttgart, Musée d'Archéologie Nationale Saint-Germain-en-Laye, Museum der Stadt Worms Worms im Andreasstift, Natural History Museum Mainz, private Collection Klaus Paysan, Reiss-Engelhorn Museen Mannheim, 
Romano-Germanic Central Museum in Mainz, Senckenberg Research Institute Frankfurt/Main, Museum im Gelben Haus in Esslingen, University of Mainz. The Institute of Geosciences at the University of Mainz is thanked for providing parts of the equipment.

Author Contributions: Sebastian Fürst, Christopher F.E. Pare and Ina Reiche conceived of and designed the experiments. Ludovic Bellot-Gurlet, Katharina Müller, Céline Paris, Liliana Gianni and Ina Reiche performed the experiments. Liliana Gianni and Katharina Müller analyzed the data. Sebastian Fürst, Katharina Müller and Ina Reiche wrote the paper.

Conflicts of Interest: The authors declare no conflict of interest.

\section{References}

1. Liverino, B. Red Coral; Jewel of the Sea: Bologna, Italy, 1989.

2. Skeates, R. Mediterranean coral: Its use and exchange in and around the Alpine region during the later neolithic and copper age. Oxf. J. Archaeol. 1993, 108, 281-292. [CrossRef]

3. Henn, U. Korallen im Edelstein-und Schmuckhandel. Zeitschr. Dt. Gemmol. Ges. 2006, 55, 77-104. (In German)

4. Tescione, G. Il Corallo Nella Storia e Nell' Arte; Montanino: Neapel, Italy, 1965. (In Italian)

5. Galasso, M. Korallenfischerei in Sardinien. Archäologische Zeugnisse und Dokumente von der Vorgeschichte bis heute. Skyllis 2000, 3, 80-113. (In German)

6. Tsounis, G.; Rossi, S.; Gili, J.-M.; Arntz, W.E. Red coral fishery at the Costa Brava (NW Mediterranean): Case study of an overharvested precious Coral. Ecosystems 2007, 10, 975-986. [CrossRef]

7. Bussoletti, E., Cottingham, D., Bruckner, A.W., Roberts, G.G., Sandulli, R., Eds.; Proceedings of the International Workshop on Red Coral Science, Management, and Trade: Lessons from the Mediterranean; NOAA Technical Memorandum CRCP-13; National Oceanic and Atmospheric Administration: Silver Spring, MD, USA, 2010.

8. Rolandi, V. Gems from the animal kingdom: A gemmological study of materials from cnidaria. Rendiconti 1981, 37, 703-718.

9. Tsounis, G.; Rossi, S.; Grigg, R.; Santangelo, G.; Bramanti, L.; Gili, J.-M. The exploitation and conservation of precious corals. Oceanogr. Mar. Biol. 2010, 48, 161-212.

10. Lacaze-Duthiers, H. Histoire Naturelle du Corail: Organisation, Reproduction, Pèche en Algerie, Industrie et Commerce; J.B. Ballière et Fils Publisher: Paris, France, 1864. (In French)

11. Smith, C.P.; McClure, S.F.; Eaton-Magaña, S.; Kondo, D.M. Pink-to-red coral: A guide to determining origin of color. Gems Gemol. 2007, 43, 4-15. [CrossRef]

12. Dauphin, Y. Mineralizing matrices in the skeletal axes of two Corallium species (Alcyonacea). Comp. Biochem. Physiol. A 2006, 145, 54-64. [CrossRef] [PubMed]

13. Vielzeuf, D.; Garrabou, J.; Barronet, A.; Grauby, O.; Marschal, C. Nano to macroscale biomineral architecture of red coral (Corallium rubrum). Am. Miner. 2008, 93, 1799-1815. [CrossRef]

14. Harmelin, J.-G. Le corail rouge de Méditerranée: Quelques aspects de sa biologie et de son écologie. In Corallo di Ieri, Corallo di Oggi: Atti del Convegno, Ravello, Villa Rufolo, 13-15 Dicembre 1996; Morel, J.-P., Rondi-Costanzo, C., Ugolini, D., Eds.; Edipuglia: Bari, Italy, 2000; pp. 11-20. (In French)

15. Allemand, D.; Bénazet-Tambutté, S. Dynamics of calcification in the Mediterranean red coral, Corallium rubrum (Linnaeus) (Cnidaria, Octocorallia). J. Exp. Zool. 1996, 276, 270-278. [CrossRef]

16. Vielzeuf, D.; Garrabou, J.; Gagnon, A.; Ricolleau, A.; Adkins, J.; Günther, D.; Hametner, K.; Devidal, J.-L.; Reusser, E.; Perrin, J.; et al. Distribution of sulphur and magnesium in the red coral. Chem. Geol. 2013, 355, 13-27. [CrossRef]

17. Perrin, J.; Vielzeuf, D.; Ricolleau, A.; Dallaporta, H.; Valton, S.; Floquet, N. Block-by-block and layer-by-layer growth modes in coral skeletons. Am. Miner. 2015, 100, 681-695. [CrossRef]

18. Urmos, J.; Sharma, S.K.; Mackenzie, F.T. Characterization of some biogenic carbonates with Raman spectroscopy. Am. Miner. 1991, 76, 641-646.

19. Parker, J.E.; Thompson, S.P.; Lennie, A.R.; Potter, J.; Tang, C.C. A study of the aragonite-calcite transformation using Raman spectroscopy, synchrotron powder diffraction and scanning electron microscopy. CrystEngComm 2010, 12, 1590-1599. [CrossRef]

20. Merlin, J.C.; Dele, M.L. Étude par spectroscopie Raman de résonance de la pigmentation des squelettes calcaires de certains coraux. Bull. Soc. Zool. Fr. 1983, 108, 289-301. (In French) 
21. Merlin, J.C.; Delé-Dubois, M.L. Resonance Raman characterization of polyacetylenic pigments found in the calcareous skeleton. Comp. Biochem. Physiol. B 1986, 84, 97-103.

22. Cvejic, J.; Tambutté, S.; Lotto, S.; Mikov, M.; Slacanin, I.; Allemand, D. Determination of canthaxanthin in the red coral (Corallium rubrum) from Marseille by HPLC combined with UV and MS detection. Mar. Biol. 2007, 152, 855-862. [CrossRef]

23. Karampelas, S. Determination by Raman scattering of the nature of pigments in cultured freshwater pearls from the mollusk Hyriopsis cumingi. J. Raman Spectrosc. 2007, 38, 217-230. [CrossRef]

24. Barnard, W.; de Waal, D. Raman investigation of pigmentary molecules in the molluscan biogenic matrix. J. Raman Spectrosc. 2006, 37, 342-352. [CrossRef]

25. Fritsch, E.; Karampelas, S. Comment on: Determination of canthaxanthin in the red coral (Corallium rubrum) from Marseille by HPLC combined with UV and MS detection (Cvejic, et al. Mar. Biol. 2007, 152, 855-862). Mar. Biol. 2007, 152, 929-930. [CrossRef]

26. Kupka, T.; Lin, H.M.; Stobiński, L.; Chen, C.-H.; Liou, W.-J.; Wrzalik, R.; Flisak, Z. Experimental and theoretical studies on corals I: Toward understandig the origin of color in precious red corals from Raman and IR spectroscopies and DFT calculations. J. Raman Spectrosc. 2010, 41, 651-658. [CrossRef]

27. Karampelas, S.; Fritsch, E.; Rondeau, B.; Andouche, A.; Métivier, B. Identification of the endangered pink-to-red stylaster corals by Raman spectroscopy. Gems Gemol. 2009, 49, 48-52. [CrossRef]

28. Bergamonti, L.; Bersani, D.; Mantovan, S.; Lottici, P.P. Micro-Raman investigation of pigments and carbonate phases in corals and molluscan shells. Eur. J. Mineral. 2013, 25, 845-853. [CrossRef]

29. Soldati, A.L.; Jacob, D.E.; Wehrmeister, U.; Häger, T.; Hofmeister, W. Micro-Raman spectroscopy of pigments contained in different calcium carbonate polymorphs from freshwater cultured pearls. J. Raman Spectrosc. 2008, 39, 525-536. [CrossRef]

30. Koenig, M.-P. L'emploi du corail dans la parure hallstattienne d'alsace. Cah. Alsac. Arch. 1987, 30, 91-101. (In French)

31. Müller, F. Überraschendes unter der Patina einer keltischen Fibel aus Münsingen. Arch. Schweiz 1993, 16, 60-64. (In German)

32. Weiß, M.; von Zelewski, B. Untersuchungen zu einigen Ziereinlagen. In Waldalgesheim. Das Grab Einer Keltischen Fürstin; Joachim, H.-E., Ed.; Rheinland-Verlag GmbH: Bonn, Germany, 1995; pp. 148-158. (In German)

33. Schüler, T. Röntgendiffraktometrische Untersuchungen an drei latènezeitlichen Schmuckeinlagen. Alt Thüringen 1997, 31, 57-63. (In German)

34. Bente, K.; König, A.; Dehn, F.; Krüger, P.; Münster, T.; Berthold, C.; Wirth, R. Vergleichende computertomografische und elektronenmikroskopische Studien zu eisenzeitlicher Korallenzier. Metalla Sonderbd. 2015, 7, 59-61. (In German)

35. Schrickel, M.; Bente, K.; Berthold, C.; Grill, W.; Sarge, C.; Hoppe, T. Vergleichende archäometrische Untersuchungen an Fibeln mit Korallenzier: Fragestellungen und methodischer Überblick. In Produktion-Distribution-Ökonomie: Siedlungs und Wirtschaftsmuster der Latènezeit Akten des Internationalen Kolloquiums in Otzenhausen, 28-30 Oktober 2011; Hornung, S., Ed.; Dr. Rudolf Habelt GmbH: Bonn, Germany, 2014. (In German)

36. Schrickel, M.; Bente, K.; Franz, A.; Sarge, C. Vergleichende radiographische und 3D-röntgentomographische Untersuchungen an Fibeln mit Korallenzier. In Proceedings of the Handreichung zu Einem Poster im Rahmen des Internationalen Kolloquiums "Produktion-Distribution-Ökonomie”, Otzenhausen, Lkr. St. Wendel, Germany, 28-30 October 2011. (In German).

37. Schrickel, M.; Bente, K.; Berthold, C.; Grill, W.; Tescher, U.; Scharf, O.; Hoppe, T. Rote Korallen? Archäometrische Studien an "Mitteldeutschen Korallenfibeln". In Proceedings of the Poster Präsentation auf der internat. Tagung "Rot. Die Archäologie bekennt Farbe", Halle, Germany, 4-5 October 2012. (In German).

38. Schrickel, M.; Bente, K.; Fleischer, F.; Franz, A. Importation ou imitation du corail à la fin de l'âge du Fer? Première approche par analyses du matériau. In L'âge du Fer en Aquitaine et Sur Ses Marges. Mobilité des Hommes, Diffusion des Idées, Circulation des Biens dans L'espace Européen à L'âge du Fer, Actes du 35e Colloque International de l'AFEAF, Bordeaux 2011; Colin, A., Verdin, F., Eds.; Aquitania: Pessac, France, 2013; pp. 753-759. (In French) 
39. Champion, S. Coral in Europe: Commerce and Celtic Ornament. In Celtic Art in Ancient Europe, Five Protohistoric Centuries L'Art Celtique en Europe Protohistorique: Débuts, Dévelopements, Styles, Techniques; Duval, P.-M., Hawkes, C., Eds.; Seminar Press: London, UK, 1976; pp. $29-40$.

40. Champion, S. The Use of Coral and Other Substances to Decorate Metal Work in Central and Western Europe in the Middle and Later Centuries of the First Millenium B.C. Ph.D. Thesis, Oxford University, Oxford, UK, 1977. Unpublished PhD Thesis.

41. Perrin, F. Technologie et économie du corail de Méditerranée Corallium rubrum L. en Gaule du VI ${ }^{\mathrm{e}}$ au I ${ }^{\mathrm{er}}$ siècle avant J.-C. University Paris-Sorbonne, Paris, France, 1996. Unpublished PhD Thesis (In French).

42. Morel, J.-P. Les conclusions d'un archéologue. In Corallo di ieri, corallo di oggi. Atti del convegno, Ravello, Villa Rufolo, 13-15 Dicembre 1996; Morel, J.-P., Rondi-Costanzo, C., Ugolini, D., Eds.; Edipuglia: Bari, Italy, 2000; pp. 301-303. (In French)

43. Fürst, S. Die Südwestdeutschen Korallenfunde der Hallstatt- und Frühlatènezeit im Spiegel Raman-Spektroskopischer Analysen. Johannes Gutenberg University, Mainz, Germany, 2010. [Unpublished Magister Thesis] (In German).

44. Fürst, S. Korallen am Übergang zur Frühlatènezeit: Zum wissenschaftlichen Potenzial eines problematischen Schmuckmaterials. In Produktion-Distribution-Ökonomie: Siedlungs- und Wirtschaftsmuster der Latènezeit Akten des Internationalen Kolloquiums in Otzenhausen, 28-30 Oktober 2011; Hornung, S., Ed.; Dr. Rudolf Habelt GmbH: Bonn, Germany, 2014; pp. 41-66. (In German)

45. Debreuil, J.; Tambutté, S.; Zoccola, D.; Segonds, N.; Techer, N.; Marschal, C.; Allemand, D.; Kosuge, S.; Tambutté, É. Specific organic matrix characteristics in skeletons of Corallium species. Mar. Biol. 2011, 158, 2765-2774. [CrossRef]

46. Tsounis, G. Demography, Reproductive Biology and Trophic Ecology of Red Coral (Corallium rubrum L.) at the Costa Brava (NW Mediterranean): Ecological Data as a Tool for Management. Available online: http://nbn-resolving.de/urn/resolver.pl?urn=urn:nbn:de:gbv:46-diss000012465 (accessed on 13 July 2009).

47. Boavida, J.; Paulo, D.; Aurelle, D.; Arnaud-Haond, S.; Marschal, C.; Reed, J.; Gonçalves, J.M.S.; Serrão, E.A.; Pronzato, R. A well-kept treasure at depth: precious red coral rediscovered in atlantic deep coral gardens (SW Portugal) after 300 years. PLoS ONE 2016, 11. [CrossRef]

48. Rondi-Costanzo, C.; Ugolini, D. Le corail dans le bassin nord-occidental de la Mediterranée entre le VIe et le IIe s. av. J.-C. In Corallo di ieri, Corallo di Oggi, Atti del Convegno, Ravello, Villa Rufolo, 13-15 Dicembre 1996; Morel, J.-P., Rondi-Costanzo, C., Ugolini, D., Eds.; Edipuglia: Bari, Italy, 2000; pp. 177-191. (In French)

49. Pliny the Elder. The Natural History. XXXII. Available online: http://www.perseus.tufts.edu/hopper/text? doc=Plin.+Nat.+toc (accessed on 9 June 2016).

50. Bischoff, W.D.; Sharma, S.K.; Mackenzie, F.T. Carbonate ion disorder in synthetic and biogenic magnesian calcites: A Raman spectral study. Am. Mineral. 1985, 70, 581-589.

51. Edwards Howell, G.M.; Villar Susana, E.J.; Jehlicka, J.; Munshi, T. FT-Raman spectroscopic study of calcium-rich and magnesium-rich carbonate minerals. Spectrochim. Acta Part A Mol. Biomol. Spectrosc. 2005, 61, 2273-2280. [CrossRef] [PubMed]

52. Hedegaard, C.; Bardeau, J.-F.; Chateigner, D. Molluscan shell pigments: An in situ resonance Raman study. J. Molluscan Stud. 2006, 72, 157. [CrossRef]

53. Marschal, C.; Garrabou, J.; Harmelin, J.G.; Pichon, M. A new method for measuring growth and age in the precious red coral Corallium rubrum (L.). Coral Reefs 2004, 23, 423-432. [CrossRef]

54. Fürst, S.; Müller, K.; Paris, C.; Bellot-Gurlet, L.; Pare, C.F.E.; Reiche, I. Neue Identifizierungsstrategie eisenzeitlicher Korallen anhand optischer und Raman-spektroskopischer Charakteristiken. Berl. Beitr. Archäom. Kunsttechnol. Konservierungswissenschaft 2014, 22, 25-35. (In German)

55. Cuif, J.-P.; Dauphin, Y.; Sorauf, J.E. Biominerals and Fossils through Time; Cambridge University Press: Cambridge, UK, 2011.

56. McGregor, H.V.; Gagan, M.K. Diagenesis and geochemistry of Porites corals from Papua New Guinea: Implications for paleoclimate reconstruction. Geochim. Cosmochim. Acta 2003, 67, 2147-2156. [CrossRef]

57. Müller, K.; Chadefaux, C.; Thomas, N.; Reiche, I. Microbial attack of archaeological bones versus high concentrations of heavy metals in the burial environment. A case study of animal bones from a mediaeval copper workshop in Paris. Palaeogeogr. Palaeoclimatol. Palaeoecol. 2011, 310, 39-51. [CrossRef]

58. Kimmig, W. Les tertres funéraires préhistoriques dans la forêt de Haguenau: Rück- und Ausblick. Prähist. Zeitschr. 1979, 54, 47-176. (In French) [CrossRef] 
59. Wigg, A. Koralle und Email als Einlage bei Metallarbeiten. In Hundert Meisterwerke Keltischer Kunst: Schmuck und Kunsthandwerk Zwischen Rhein und Mosel; Cordie-Hackenberg, R., Born, H., Eds.; Rheinisches Landesmuseum: Trier, Germany, 1992; pp. 207-209. (In German)

60. Koenig, M.-P. Haguenau: trois ensembles avec or et corail. In Trésors Celtes et Gaulois: Le Rhin Supérieur Entre 800 et 50 Avant J.-C. Exposition Présentée au Musée d'Unterlinden du 16 Mars au 2 Juin 1996; Plouin, S., Ed.; Direction Régionale des Affaires Culturelles d'Alsace: Colmar, France, 1996; pp. 88-93. (In French)

61. Stöllner, T. "Verborgene Güter"-Rohstoffe und Spezereien als Fernhandelsgut in der Späthallstatt- und Frühlatènezeit. In Die Hydria von Grächwil, Zur Funktion und Rezeption Mediterraner Importe in Mitteleuropa im 6. und 5. Jahrhundert v. Chr. Internationales Kolloquium, 12-13 Oktober 2001; Guggisberg, M.A., Ed.; Bernisches Historisches Museum: Bern, Switzerland, 2004. (In German)

62. Bersani, D.; Lottici, P.P. Applications of Raman spectroscopy to gemology. Anal. Bioanal. Chem. 2010, 397, 2631-2646. [CrossRef] [PubMed]

63. Reiche, I.; Pages-Camagna, S.; Lambacher, L. In situ Raman spectroscopic investigations of the adorning gemstones on the reliquary Heinrich's Cross from the treasury of Basel Cathedral. J Raman Spectrosc. Spec. Issue Raman Spectrosc. Art Archaeol. 2004, 35, 719-725.

(C) 2016 by the authors; licensee MDPI, Basel, Switzerland. This article is an open access article distributed under the terms and conditions of the Creative Commons Attribution (CC-BY) license (http://creativecommons.org/licenses/by/4.0/). 